\title{
Biosilicification Drives a Decline of Dissolved Si in the Oceans through Geologic Time
}

\begin{abstract}
Daniel J. Conley ${ }^{1,2 *}$, Patrick J. Frings ${ }^{1,3+}$, Guillaume Fontorbe ${ }^{1}$, Wim Clymans ${ }^{1,4}$, Johanna Stadmark ${ }^{1}$, Katharine R. Hendry ${ }^{5}$, Alan O. Marron ${ }^{6}$ and Christina L. De La Rocha ${ }^{1}$

${ }^{1}$ Department of Geology, Lund University, Lund, Sweden, ${ }^{2}$ Stellenbosch Institute for Advanced Study, Stellenbosch, South Africa, ${ }^{3}$ Department of Geoscience, Swedish Museum of Natural History, Stockholm, Sweden, ${ }^{4}$ Earthwatch Institute, Oxford, United Kingdom, ${ }^{5}$ School of Earth Sciences, University of Bristol, Bristol, United Kingdom, ${ }^{6}$ Department of Applied Mathematics and Theoretical Physics, Centre for Mathematical Sciences, University of Cambridge, Cambridge, United Kingdom
\end{abstract}

OPEN ACCESS

Edited by:

Stephen B. Baines, Stony Brook University, United States

Reviewed by:

X. Antón Álvarez-Salgado, Consejo Superior de Investigaciones Científicas (CSIC), Spain

Dirk De Beer,

Max Planck Society (MPG), Germany

*Correspondence: Daniel J. Conley daniel.conley@geol.lu.se

${ }^{\dagger}$ Present Address: Patrick J. Frings, Earth Surface Geochemistry, Helmholtz Centre Potsdam, GFZ

German Research Centre for Geosciences, Potsdam, Germany

Specialty section:

This article was submitted to Marine Biogeochemistry, a section of the journal Frontiers in Marine Science

Received: 14 April 2017 Accepted: 24 November 2017 Published: 11 December 2017

Citation:

Conley DJ, Frings PJ, Fontorbe G, Clymans W, Stadmark J, Hendry KR, Marron $A O$ and De La Rocha CL (2017) Biosilicification Drives a Decline of Dissolved Si in the Oceans through Geologic Time. Front. Mar. Sci. 4:397. doi: 10.3389/fmars.2017.00397
Biosilicification has driven variation in the global Si cycle over geologic time. The evolution of different eukaryotic lineages that convert dissolved Si (DSi) into mineralized structures (higher plants, siliceous sponges, radiolarians, and diatoms) has driven a secular decrease in DSi in the global ocean leading to the low DSi concentrations seen today. Recent studies, however, have questioned the timing previously proposed for the DSi decreases and the concentration changes through deep time, which would have major implications for the cycling of carbon and other key nutrients in the ocean. Here, we combine relevant genomic data with geological data and present new hypotheses regarding the impact of the evolution of biosilicifying organisms on the DSi inventory of the oceans throughout deep time. Although there is no fossil evidence for true silica biomineralization until the late Precambrian, the timing of the evolution of silica transporter genes suggests that bacterial silicon-related metabolism has been present in the oceans since the Archean with eukaryotic silicon metabolism already occurring in the Neoproterozoic. We hypothesize that biological processes have influenced oceanic DSi concentrations since the beginning of oxygenic photosynthesis.

Keywords: silicates, diatoms, sponges, cyanobacteria, biogeochemical cycles

\section{INTRODUCTION}

Seminal work published a quarter of a century ago sketched a framework for the evolution of the oceanic Si cycle through Earth's history based on the geological record available at that time (Figure 1A). The narrative given by Maliva et al. (1989) and Siever (1991) suggested that, in the absence of silica biomineralizers, defined here as organisms that intentionally take dissolved $\mathrm{Si}$ (DSi) up across their cell membrane and control its precipitation as particulate silica to form a structure that is then used in a specific manner, the Precambrian Si cycle was dominated by inorganic reactions and diagenetic silicification. These processes resulted in the widespread deposition of cherts and ultimately controlled concentrations of DSi in the oceans. A biological takeover of oceanic DSi occurred with the evolution of silica biomineralizing eukaryotes during the Phanerozic and the subsequent deposition of DSi as biogenic Si (BSi). This simple framework divides the ocean Si cycle into periods of relative stasis separated by stepwise drops in ocean DSi 

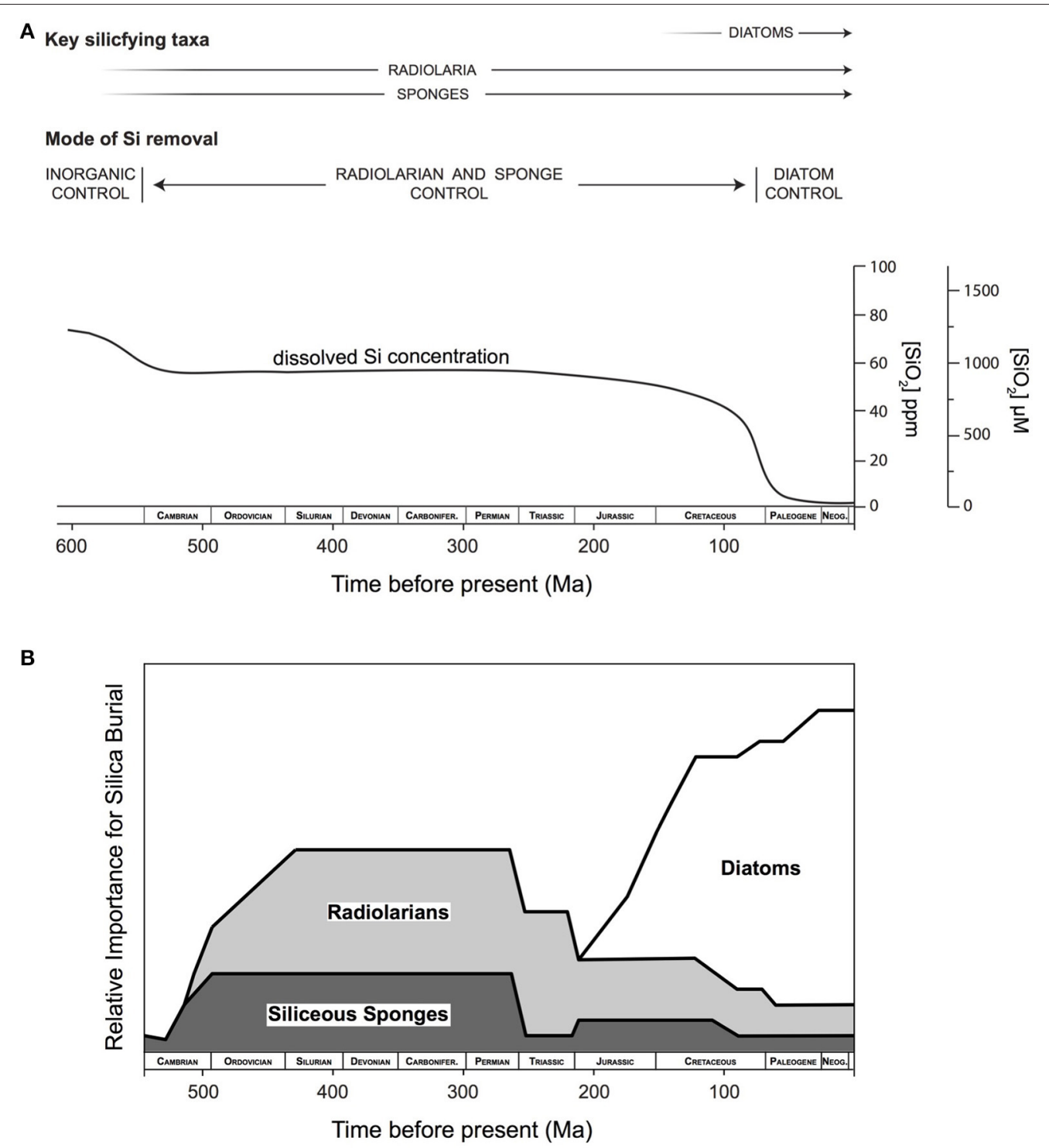

FIGURE 1 | The evolution of the oceanic Si cycle in the geologic record from the latest Precambrian to the present envisioned by Siever (1991). (A) In the absence of biosilicifiers dissolved Si (DSi) concentrations were determined by inorganic reactions with respect to amorphous silica solubility and/or with other Si-bearing phases. With the appearance of sponges and radiolarians in the early Phanerozoic biomineralization caused drawdown of DSi concentrations. However, DSi was rapidly reduced with the evolution and diversification of diatoms during the Cenozoic time period. From Schneider and Boston (1991) by permission of The MIT Press. (B) Qualitative interpretation of the relative role of the importance of radiolarians, sponges and diatoms present in the fossil record though geologic time (Redrawn from Kidder and Erwin, 2001). Reproduced with permission @2001, The University of Chicago Press.

concentrations related to the appearance of various $\mathrm{Si}$ biomineralizing organisms starting with sponges and radiolarians in the early Phanerozic, followed by the radiation of diatoms in the Cenozoic (Figure 1B). In the decades since its publication, this paradigm has guided thinking on the Si cycle and on the evolution and distribution of Si biomineralizing organisms.

Part of the reason for the longevity of this simple view is that many features of the global Si cycle through geologic time remain poorly characterized and understood. For example, we do not have a good understanding of changes in the inputs of DSi to the ocean from continental weathering, although the flux of DSi solubilized from continental rocks has inevitably varied appreciably over Earth history in response to changing climatic or tectonic boundary conditions. One example of this is orogeny, which plays a critical role in controlling weathering intensity and secondary mineral formation, thereby influencing both the total DSi flux and its isotopic composition (Frings et al., 2015, 2016; Pogge von Strandmann and Hendersen, 2015). Thus while it is tempting to interpret changes in the quality or 
quantity of siliceous marine sediments in the geologic record in terms of the prevailing DSi concentrations in the ocean, or evolutionary breakthroughs in biomineralization, there may also be a climatic or tectonic component to the signal, independent of biological cycling. Altogether, we lack a comprehensive understanding of the evolution of the Si cycle through geologic time.

At the same time, our understanding of the biological components of the Si cycle has grown enormously since the classic work of Siever, Maliva and co-workers. We appreciate the ability of organisms to pump DSi across membranes (Hildebrand, 2000) and how sequestration of Si by biomineralizing organisms influences the availability of DSi in aquatic ecosystems. We also have a great appreciation of the ecological roles of $\mathrm{Si}$ biomineralizers and their participation in other biogeochemical cycles (Van Cappellen, 2003). Study of Si cycling through ecologically important biomineralizing organisms in both aquatic (Knoll, 2003) and terrestrial environments (TrembathReichert et al., 2015) has identified and quantified many rates, reservoirs, and processes whose development, expansion, and variation over space and time has added complexity to not just the Si cycle but to ecosystems and the biogeochemical cycles intertwined with the Si cycle.

This is not just relevant to the Phanerozoic, when Si biomineralization irrefutably exists. Although earlier fossil evidence for silicifying organisms is scarce, and often controversial (Porter and Knoll, 2000; Sperling et al., 2010; Antcliffe et al., 2014; Chang et al., 2017), study of the evolutionary history of Si transporters used in biosilicification indicates a remarkably early appearance of transmembrane Si transport in eukaryotes. This challenges the hypothesis that the Precambrian oceans were controlled only by inorganic reactions. Instead, we suggest that oceanic DSi concentrations have both influenced and been influenced by the appearance and diversification of the Silicon Transporter (SIT) gene family roughly 2 billion years before the Phanerozoic (Marron et al., 2016).

In our analysis here, based on advances from fields ranging from biogeochemistry (Baines et al., 2012; Frings et al., 2016) to geogenomics (Baker et al., 2014; Marron et al., 2016), we assess our state of knowledge of the global Si cycle emphasizing the substantial advances that have emerged in the past quarter of a century. We will explore the possible levels of DSi in the oceans over geologic time based on evidence from the geologic record as well as concerning the evolution of the SIT gene family. Our aim with this assessment of the potential for biosilicification over geologic time is to help establish a basis for future research directions.

\section{BIOGEOCHEMISTRY OF SILICA IN THE OCEANS}

Two reasons for studying the Si cycle are commonly put forward. First, the process of the chemical weathering of silicate minerals is a primary drawdown mechanism of atmospheric $\mathrm{CO}_{2}$ and is a key process in the geological C cycle (Walker et al., 1981). Therefore, understanding the global Si cycle can provide insight to the functioning of the weathering thermostat (Pogge von
Strandmann et al., 2017). Second, DSi is a required nutrient for many organisms, both aquatic (Bowler et al., in review) and terrestrial (Conley and Carey, 2015). The availability of DSi in aquatic ecosystems controls the amount of diatom primary productivity, which today account for $40 \%$ of ocean primary productivity (Tréguer and De La Rocha, 2013).

Key aspects of the modern oceanic Si cycle have been explored to quantify the processes, sources, reservoirs, and sinks in the Si cycle (Tréguer and De La Rocha, 2013; Frings et al., 2016). The primary Si source is low-temperature chemical weathering of silicates in the continental crust (West et al., 2005; Misra and Froelich, 2012; Pogge von Strandmann and Hendersen, 2015), a process mediated in no small part by biological activity (Moulton and Berner, 1988). Other Si sources include high or low temperature alteration of ocean crust (McKenzie et al., 2016), and the dissolution of glacial (Hawkings et al., 2017), riverine, or aeolian particulates containing Si (Frings et al., 2014). The sources enter the ocean from rivers, meltwaters, groundwaters, as hydrothermal fluids and from the atmosphere (Tréguer and De La Rocha, 2013). The sinks include biosilicification and burial (Knoll, 2003) and the authigenesis of clay minerals (Mackenzie et al., 1967; Rahman et al., 2016).

Simple box models have been commonly used to provide insight into the long-term marine $\mathrm{Si}$ cycle (De La Rocha and Bickle, 2005; Yool and Tyrrell, 2005; Frings et al., 2016). For periods of time longer than the oceanic turnover time of DSi (ca. 10,000 years), global biosiliceous production is regulated by both the sources and the sinks of Si to the oceans. One of the key regulatory mechanisms is the dependence of particulate amorphous $\mathrm{Si}$ dissolution rates on ambient DSi concentrations, e.g.,

$$
\mathrm{R}=\mathrm{k} \cdot\left(1-\mathrm{DSi}_{\mathrm{obs}} / \mathrm{DSi}_{\mathrm{sat}}\right)
$$

where $\mathrm{R}$ is the rate of dissolution and $\mathrm{k}$ is a rate constant, both in units of inverse time. $\mathrm{k}$ depends on a variety of factors including the specific surface area of the particle, its aluminum content, and ambient pressure, $\mathrm{pH}$ and temperature (Van Cappellen et al., 2002). DSi $i_{\text {sat }}$ is the apparent solubility and DSi $i_{\text {obs }}$ is the ambient DSi concentration. When DSi concentrations are high, such as hypothesized for the Phanerozoic (Siever, 1992) the rate of dissolution of particulate amorphous $\mathrm{Si}$ is slow and the preservation efficiency is thus enhanced. This is also due to the build-up of DSi in pore waters that enhances the preservation and ultimate burial of BSi. Conversely, when the oceans are depleted of DSi the larger difference between saturation and ambient concentration drives the dissolution of particulate amorphous Si.

Several other important factors influence the preservation of $\mathrm{BSi}$ in different geological settings. First, bacteria-mediated degradation of the organic matrix covering biomineralized cells enhances rates of BSi dissolution (Bidle and Azam, 1999), an effect which is greater in warmer waters both due to higher bacterial activity and by the more rapid dissolution of the BSi thus exposed (Bidle et al., 2002). Secondly, during periods when hypoxia and anoxia are prevalent there are fewer benthic organisms to enhance dissolution rates by consuming organic material and disturbing the sediments. The lack of benthic organisms and especially of bioturbation leads to greater 
preservation of organic matter (Jessen et al., 2017) and BSi. Finally, the dissolution rates of sponge spicules (Bertolino et al., 2017), which are large, smooth and have low surface area (Uriz, 2006), are conspicuously slower (and sponge spicules are thus more easily preserved) than diatoms or radiolarians, which are riddled with pores, and can be amoured with spines.

\section{CHANGING SI BIOGEOCHEMISTRY IN THE PRECAMBRIAN OCEANS}

Siever (1992) postulated that for the early period in the geologic history of the Earth, the oceanic Si cycle must be thought of as one primarily controlled by abiotic, inorganic reactions. The diagenetic production of chert in marine environments was widespread during the Precambrian (Maliva et al., 1989, 2005; Siever, 1992; Konhauser et al., 2007) and Siever (1992) suggested that DSi in the Precambrian ocean was close to saturation with respect to amorphous $\mathrm{Si}$, which would imply DSi concentrations in the range of 1,250-2,200 $\mu \mathrm{M}$ (Gunnarsson and Arnórsson, 2000). However, recent work has highlighted the role of different Si-bearing phases in controlling oceanic DSi concentrations (e.g., Fischer and Knoll, 2009; Zheng et al., 2016). Essentially, the problem lies in determining which Si phase(s) that may have occurred in the ancient ocean were governing the activity of DSi. This is a complex function of mineral thermodynamics, precipitation kinetics and ocean chemistry.

During much of the Archean, and more sporadically in the Proterozoic, thinly bedded or laminated sedimentary rocks containing on average $30 \%$ of iron and $40 \%$ or more of Si (Klein, 2005) were formed in marine basins in stratified water columns. These banded iron formations (BIFs) were mostly deposited prior to the initial rise of atmospheric oxygen at $\sim 2.45 \mathrm{Ga}$ (Kump, 2008) when the ocean was anoxic and rich in dissolved iron. Dissolved ferrous iron, supplied from mid-ocean ridges and hydrothermal vents, was oxidized by various processes to ferric iron and deposited in association with $\mathrm{Si}$ in BIFs.

A number of mechanisms have been proposed to account for the massive deposition of Fe- and Si-rich sediments throughout much of the Precambrian and most of them do not involve biology (see Fischer and Knoll, 2009). However, oxidation of iron by organisms, such as cyanobacteria, in the water column may have played a key role in the formation of some of the BIFs (Rasmussen et al., 2015). Once formed, this biologically oxidized iron would have efficiently scavenged DSi from the water around it (Yee et al., 2003) and settled to the seabed. Indeed, recent studies have highlighted the importance of amorphous Fe-Si gels in the Precambrian Si cycle (Fischer and Knoll, 2009; Zheng et al., 2016). When ferrous iron is oxidized by anoxygenic photosynthesis (e.g., Chi Fru et al., 2013) or by photo-oxidation (e.g., Braterman et al., 1983) DSi readily adsorbs to the ferric hydroxide surface leading to the formation of particles, e.g., amorphous $\mathrm{Fe}$ (III)-Si gels, that sink to the sediments from the surface ocean along with organic matter (Fischer and Knoll, 2009).

If DSi concentrations in Precambrian seawater were determined only by the solubility of amorphous $\mathrm{Si}$, as well as by sorption to minerals, oceanic DSi concentrations would have ranged between 1,000 and 2,000 $\mu \mathrm{M}$ (Siever, 1992; Maliva et al., 2005; Konhauser et al., 2007). By contrast, Si solubility for $\mathrm{Fe}(\mathrm{III})-\mathrm{Si}$ gels varies between 500 and $1,500 \mu \mathrm{M}$ at $20^{\circ} \mathrm{C}$ as a function of the Fe/Si ratio of the gel (Zheng et al., 2016), significantly lower than that of pure amorphous Si $(1,860 \mu \mathrm{M})$ in water (Gunnarsson and Arnórsson, 2000). Thus Precambrian seawater DSi concentrations in surface waters were likely considerably lower than previous estimates.

Because the solubility of $\mathrm{Fe}(\mathrm{III})-\mathrm{Si}$ gel varies with the $\mathrm{Fe} / \mathrm{Si}$ ratio in the water column, any temporal changes in aqueous Fe contents in the Precambrian oceans, as might occur due to changes in hydrothermal inputs or concentrations of oxygen, may have also had an important impact on DSi concentrations in Precambrian seawater as well as other elements, notably other trace metals, such as $\mathrm{P}, \mathrm{As}, \mathrm{Fe}, \mathrm{Zn}$, and Cu (Rickaby, 2015; Chi Fru et al., 2016).

Changing Fe and Si balances in the Archean and Proterozoic oceans, reflecting changes in Si solubility driven by aqueous $\mathrm{Fe}(\mathrm{II})$ levels, may help explain the secular trend in Si isotope records $\left(\delta^{30} \mathrm{Si}\right)$ in cherts and BIFs deposited during the Precambrian (Figure 2) (Reddy et al., 2016). Though the data are noisy, Precambrian cherts record $\delta^{30} \mathrm{Si}$ of $\sim 0 \%$ o in the Archean, rising to $\sim 2 \%$ in the Mesoproterozoic-with some isolated individual values of $>4 \%$ - before declining to Archean values in the late Neoproterozoic/early Phanerozoic. This long-term pattern has been noted before (e.g., Robert and Chaussidon, 2006; Chakrabarti et al., 2012; Chakrabarti, 2015) but remains enigmatic. Given that the BIF and chert $\delta^{30} \mathrm{Si}$ record is one of the few windows to Precambrian Si cycling, understanding its drivers should be a priority. Robert and Chaussidon (2006) interpret the data as variable fractions of ocean Si removed by hydrothermal silificication, while Chakrabarti et al. (2012) favor a combination of different processes acting in concert.

The constraint of mass-balance in the $\mathrm{Si}$ cycle is a useful place to start-even for an ocean saturated with respect to $\mathrm{Si}$, the residence time of Si would be ca. 200,000 years, assuming that the inputs were not drastically different to present. This means the weighted mean of the isotopic composition of the outputs must match the inputs over timescales longer than this. The Archean data (Figure 2B) thus have a straightforward interpretation: BIFs have low $\delta^{30} \mathrm{Si}$, perhaps accentuated by the relatively large and negative fractionation between DSi and $\mathrm{Fe}$ Si gels $\left(\Delta^{30} \mathrm{Si}=-3.2\right.$ to $-2.3 \%$ at $23^{\circ} \mathrm{C}$, depending on the Fe species present; Zheng et al., 2016). This would act to push the residual seawater toward higher $\delta^{30} \mathrm{Si}$, so the peritidal, early diagenetic Si deposits that eventually became cherts also have higher $\delta^{30} \mathrm{Si}$, and the two outputs together bracket ca. -1.5 to $+1 \%$, a range which includes reasonable values for the weighted average of the inputs. Yet the situation in the Meso- and Neoproterozoic is not so straightforward; chert $\delta^{30} \mathrm{Si}$ is higher, yet BIF deposition (providing the necessary complementary low $\delta^{30} \mathrm{Si}$ sink) largely ceases after the Great Oxidation Event (GOE) at $2.45 \mathrm{Ga}$ (Fischer and Knoll, 2009). This requires the presence of another, low $\delta^{30} \mathrm{Si}$ Si sink in the later Proterozoic. Could such a sink be related to cyanobacteria shuttling Si to the deep ocean? 


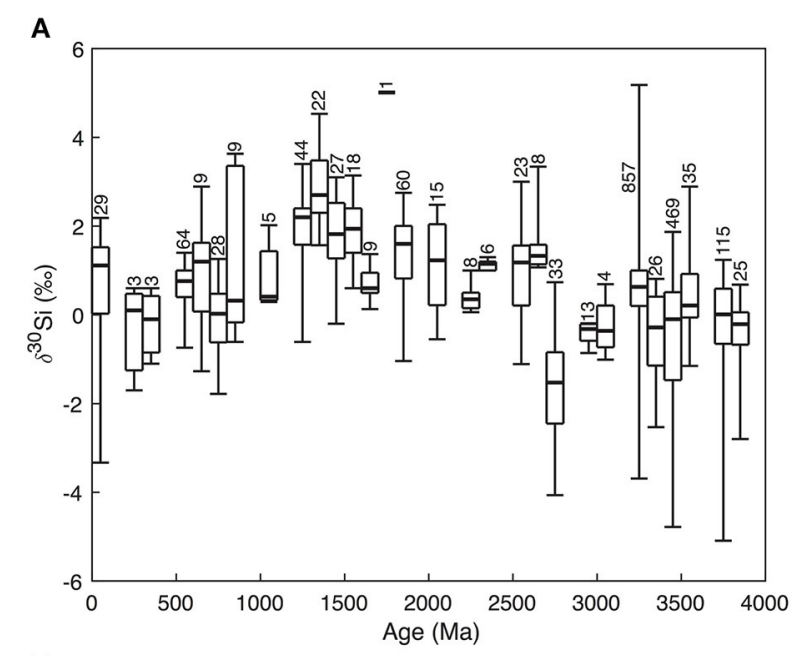

B

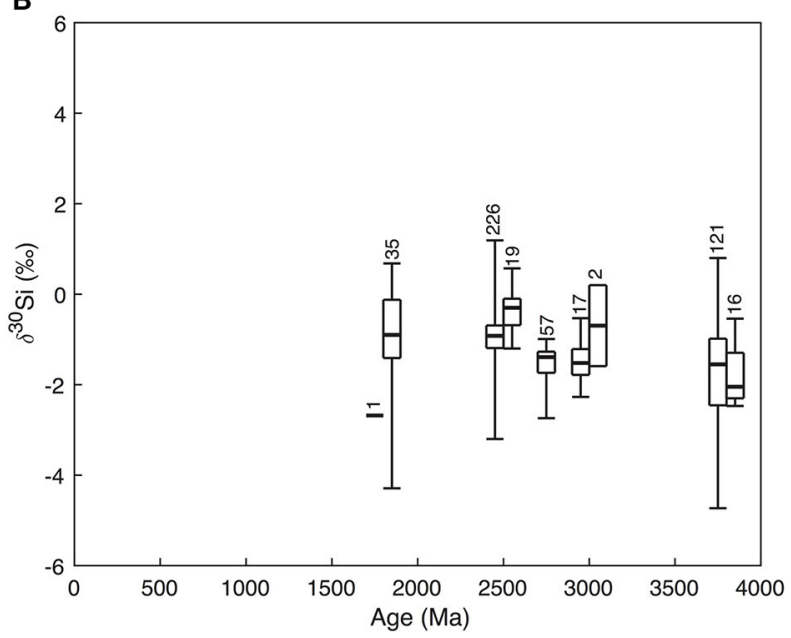

FIGURE 2 | Variations of $\delta^{30} \mathrm{Si}$ in cherts (A) and BIFs (B) with geological age. The data are clustered into $100 \mathrm{My}$ bins. Numbers represent the amount of individual datapoints used in the whisker boxes. Data from André et al. (2006), Robert and Chaussidon (2006), van den Boorn et al. (2007, 2010), Steinhoefel et al. (2009, 2010), Abraham et al. (2011), Heck et al. (2011), Chakrabarti et al. (2012), Delvigne (2012), Marin-Carbonne et al. (2014), Hu et al. (2013), Ramseyer et al. (2013), Geilert et al. (2014), Li et al. (2014), Brengman (2015), Stefurak et al. (2015), Delvigne et al. (2012), Wen et al. (2016), and Ding et al. (2017).

Recently, Ding et al. (2017) reported $\delta^{30}$ Si data for cherts from early and middle Proterozoic carbonate rocks and proposed that there was a drastic decrease in oceanic DSi concentrations and an increase in $\delta^{30} \mathrm{Si}$ due to biological activity and the formation of stromatolites. The microbial role in hot spring silicification of stromatolites is well established and plays an important templating role for Si deposition (Konhauser et al., 2004), although they have been shown to contribute only marginally to the magnitude of silicification.

Another intriguing wrinkle to the Precambrian Si cycle has to do with cyanobacteria. Synchrotron XRF microscopy of natural and cultured individual cells of the modern marine photosynthetic picocyanobacteria Synechococcus, suggests that they accumulate $\mathrm{Si}$ at $\mathrm{Si}: \mathrm{P}$ levels approaching that of diatoms (Baines et al., 2012). Further, decomposition of Synechococcus has been shown to produce extracellular polymeric substances (EPS) that themselves drive the production of minuscule "microblebs" of silica that, by adding dense ballast to aggregates, may enhance the export of picoplankton-derived material from the euphotic zone (Tang et al., 2014). These findings were initially controversial, especially as they have potentially significant importance to both carbon and Si cycling.

During the past few decades significant efforts have been made to infer the age of major evolutionary events along the tree of life using fossil-calibrated molecular clock-based methods (Eme et al., 2014). Molecular clocks use the mutation rate of biomolecules to deduce the time in prehistory when two or more life forms diverged. The main problems with molecular clocks include differences in fossil-based calibration points, differences in molecular clock rate models, differences in amino acid substitution rates among various parts of the dataset and uncertainty in the phylogenetic tree, thus limiting the precision that can be achieved in estimates of ancient molecular timescales (dos Reis et al., 2015). Cyanobacteria are at least 2.33 Ga old from molecular clock studies (Dvorák et al., 2014; Sanchez-Baracaldo, 2015), whereas fossil evidence (stromatolites, microfossils, carbon isotopes, biomarkers, signs of oxygen) from Greenland, Australia and elsewhere have raised the possibility of cyanobacteria older than $3 \mathrm{~Gy}$, although these claims are disputed (Schirrmeister et al., 2016).

The major lineage of planktonic marine Synechococcus evolved approximately $650-600 \mathrm{Ma}$, based on molecular clock analyses (Sanchez-Baracaldo, 2015; Sanchez-Baracaldoa et al., 2017), with alternative clock analyses based on large genomic datasets suggesting an origin $\sim 1.5$ Ga (Dvorák et al., 2014). Today this cyanobacterial group accounts for $25 \%$ of oceanic net primary production (Flombaum et al., 2013). Marron et al. (2016) has observed SIT-like (SIT-L) genes in two strains of Synechococcus. These Si transporters probably arose initially to prevent intracellular Si toxicity in the high DSi Precambrian oceans (Marron et al., 2016), meaning that they were used to transport $\mathrm{Si}$ out of the cell, or to sites where $\mathrm{Si}$ could be safely accumulated and sequestered. This would have been critical for survival, for in the absence of such a Si homeostasis mechanisms DSi could diffuse into cells from the surrounding DSi saturated seawater and reach concentrations where it would precipitate freely within the cytoplasm, interfering with cellular processes and disabling the functioning of the cell (Marron et al., 2016). Si transporting proteins can also have the ability to move other metalloids such as Ge (Durak et al., 2016) and As (Ma et al., 2008) across the cell membrane. Therefore Precambrian organisms, long before the advent of silica biomineralization, may have possessed and utilized Si transporting proteins as a detoxification mechanism particularly necessary in the high DSi environments at this time.

The reduced requirement for $\mathrm{Si}$ homeostasis in the modern low DSi oceans is postulated to be the reason for the widespread absence of SIT-Ls in most bacteria. However, some Synechococcus still possess SIT-Ls and accumulate Si suggests an important role 
for Si within these cells (Baines et al., 2012; Ohnemus et al., 2016). Indeed, the water column inventory of Si in Synechococcus can exceed that of diatoms in some cases, although in today's DSi depleted oceans it is believed that most of the nanoparticles produced by Synechococcus are recycled within surface waters (Baines et al., 2012). However, BSi-like material deposited on fast settling particles containing extracellular polymeric substances associated with decomposing picophytoplankton (Figure 3) has been shown to be a relevant source of sinking particulate amorphous Si and could account for as much as $43 \%$ of the $\mathrm{C}$ export production at the Bermuda Time Series station (Tang et al., 2014).

These discoveries regarding Synechococcus support the idea that $\mathrm{Fe}-\mathrm{Si}$ nanoparticles were important in the genesis of the banded iron formations (Rasmussen et al., 2015). Stefurak et al. (2014) presented evidence that many Archean cherts were deposited predominately as primary Si grains that precipitated within oceanic waters. However, the irregular size and shape of the Si granules in cherts show that aggregates are compacted and typically Si cemented (Stefurak et al., 2014). Our hypothesis is that nanoparticles produced by Synechococcus-like bacteria, along with those inorganically formed Fe-Si nanoparticles, were deposited and accumulated in Precambrian sediments and formed the origin of the Si grains in Archean cherts (Stefurak et al., 2014).

What follows from this hypothesis is that some form of biologically-mediated silica production by prokaryotes, if not bona fide intracellularly controlled and intentional $\mathrm{Si}$ biomineralization, likely occurred in the Precambrian ocean and participated in the removal of DSi from the water column. Calculation of pools and fluxes of $\mathrm{Si}$ nanoparticles produced by Synechococcus need to be made to assess the potential contribution to the oceanic Si cycle first for modern assemblages and then through geologic time.

Geogenomic studies have identified that gene families of active Si transporters (the SIT/SIT-L and Lsi2-like transporters) are present in multiple eukaryotic supergroups (Marron et al., 2016). Furthermore, phylogenetic analyses of these genes suggest that they have an origin in the Precambrian, possibly in the last common ancestor of all eukaryotes, an organism which is estimated to have lived approximately $1.7 \mathrm{Ga}$ (Parfrey et al., 2011). Certainly there is good evidence from the available sequence data that $\mathrm{Si}$ transporters were present at the origin of major eukaryotic groups such as metazoans, haptophytes and ochrophyte stramenopiles, which have all been placed as occurring in the Precambrian (Neoproterozoic) by molecular clock analyses (Brown and Sorhannus, 2010; Parfrey et al., 2011).

The phylogenetic distribution of SITs, SIT-Ls, and Lsi2like genes identified from modern eukaryotes indicates that widespread, independent losses of some or all of these transporters occurred independently in multiple lineages (Marron et al., 2016). This is exemplified by the distribution of Si transporters in the metazoans and their sister group, the choanoflagellates (Marron et al., 2013). SIT-Ls were identified from all three of the main bilaterian groups: lophotrochozoans (polychaete annelid worms), ecdysozoans (copepods) and deuterostomes (tunicates). The branching relationships of these metazoan SIT-Ls reflects the evolutionary relationships between the bilaterian groups, supporting the hypothesis that SIT-Ls were present in their last common ancestor, with gene loss events explaining their patchy distribution (Dunn et al., 2008).

Lsi2-like transporter genes, on the other hand, are found in siliceous choanoflagellates, siliceous sponges and silicifying lophotrochozoans (brachiopods, limpets and polychaete annelid worms). Once again, the gene tree mirrors the phylogenetic relationships, with the Lsi2-like sequences from siliceous choanoflagellates having sister-group relationships to the metazoan genes, and within that siliceous sponges and lophotrochozoans each forming two distinct clades (Marron et al., 2016). This points toward the last common ancestor of choanoflagellates and metazoans possessing an Lsi2-like gene, but with it being lost in the non-siliceous choanoflagellates, non-siliceous sponges and in many bilaterian lineages.

This restricts the timing of the origin of these $\mathrm{Si}$ transporters to at least before the evolution of the metazoans, i.e., before the earliest animal fossils appear in the Ediacaran. Similarly, we can restrict the widespread loss of SIT-L and Lsi2-like genes in the metazoans until after the divergence of the three main bilaterian clades, an event dated by molecular clock analyses as occurring 688-615 Ma (dos Reis et al., 2015; Cunningham et al., 2017). There exists the potential for metazoans, in addition to other eukaryotes, to have biological interactions with DSi at this time and to have played a role in the Precambrian Si cycle.

The question as to the extent of this interaction remains open. Fossil remains of biomineralization are limited until the late Neoproterozoic (e.g., the Ediacaran calcifying animals Cloudinia and Namacalathus, Cunningham et al., 2017). Furthermore, confirmed fossil evidence of Precambrian Si biomineralization by eukaryotes is scant: microfossils proposed to represent siliceous testate amoebae date to $\sim 740 \mathrm{Ma}$ (Porter and Knoll, 2000), while fossil siliceous sponge spicules in the Precambrian remain controversial (Antcliffe et al., 2014; Chang et al., 2017). It is possible that biosilicification did occur in the Ediacaran oceans, and that there exists a long missing record of (for example) siliceous sponge spicules from that time that has been long lost to the ravages of geologic time (Sperling et al., 2010). Alternatively, it could be that eukaryotic biosilicification evolved convergently in different groups in the late Neoproterozoic, with several different sponge groups, but importantly also various protistan eukaryote taxa, independently utilizing DSi to construct skeletal elements and other structures. This hypothesis has some support from molecular biology, with some components of the biosilicification machinery (e.g., Si transporters for DSi uptake) having an ancient origin but other components (e.g., using polyamines for $\mathrm{Si}$ precipitation, use of collagen or chitin as scaffold molecules) apparently being independently recruited in different eukaryotic groups (Marron et al., 2016 and references therein).

These two theories notwithstanding, the massive proliferation of biomineralization and BSi in the fossil record at the end of the Proterozoic and into the early Palaeozoic saw large reductions in DSi, as evidenced by changes in the loci of chert precipitation in the sedimentary record (see below). The implication is that 


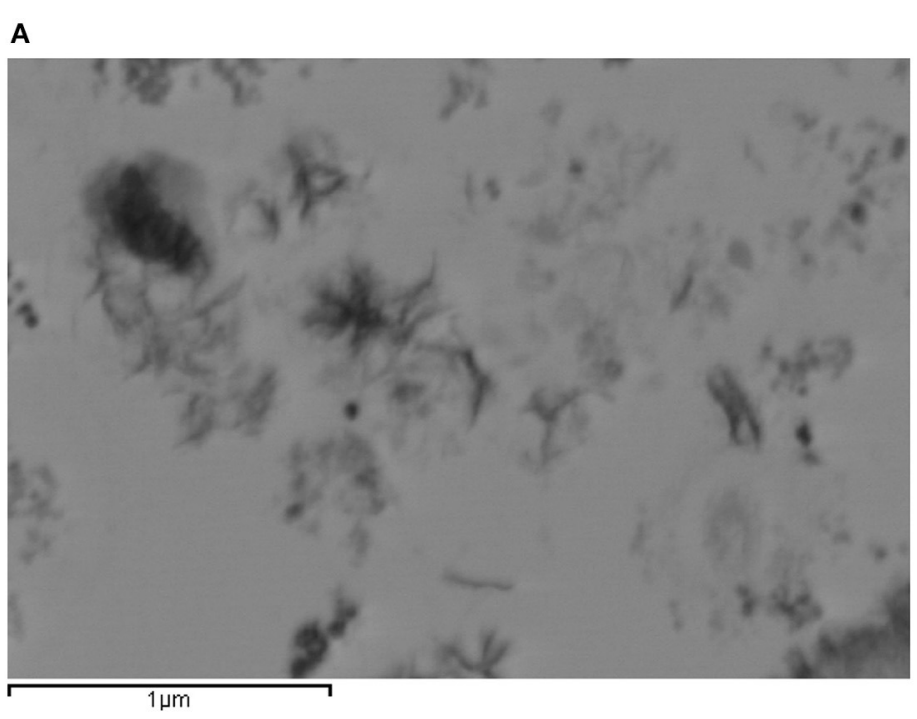

B

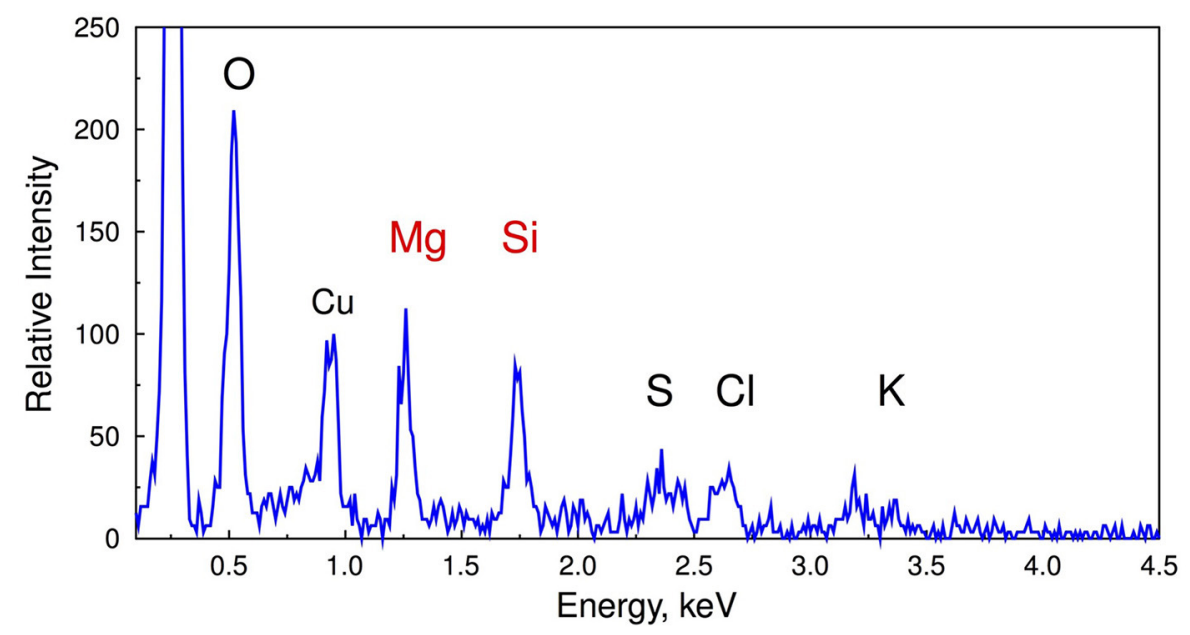

FIGURE 3 | Scanning transmission electron microscope images (A) and EDS spectra of decomposing Synechococcus cells (B) collected during dark incubation of cells after 15 days showing the association of silica with extracellular polymeric substance during the degradation of cyanobacterial cells (From Tang et al., 2014). Reprinted by permission from Macmillan Publishers Ltd: Tang et al. (2014). Copyright @) 2014.

this removed the selective pressure for possessing a system for Si homeostasis and detoxification, causing the widespread, independent losses of Si transporters (SITs, SIT-Ls, and Lsi2like transporters) across multiple different eukaryotic lineages (Marron et al., 2016). Only organisms that developed a metabolic requirement for DSi, for example for use as a biomineral, retained these transporters as a mechanism for DSi uptake from the external environment. In this way, DSi concentrations in the ocean came under more direct biological influence into the Phanerozoic.

In summary, the evidence presented suggests that biological interaction with $\mathrm{Si}$, and possibly some forms of biosilicification, was present in the Precambrian oceans. If this could have permitted the shuttling of Si from the surface oceans then levels of DSi in parts of the surface oceans could have been as low as $500 \mu \mathrm{M}$ (Zheng et al., 2016) during periods when BIFs were deposited (Fischer and Knoll, 2009), although it is likely the deep water DSi was close to saturated conditions. Bottom water DSi saturation would also increase the preservation potential in sediments of particulate $\mathrm{Si}$ formed by either gels or by nanoparticles by Synechococcus. However, when the widespread deposition of BIFs more or less ended with the appearance of an ocean containing oxygen then the Fe-Si gel deposition mechanism likely disappeared as well. Finally, the transition from bacterial to eukaryotic marine primary productivity in the Neoproterozoic was one of the most profound ecological revolutions in the Earth's history (Brocks et al., 2017), creating food webs and reorganizing the distribution of carbon and nutrients in the water column, increasing energy flow to higher trophic levels (Knoll, 2017). 


\section{BIOSILICIFICATION IN THE PALEOZOIC OCEANS}

The consensus is that throughout the Phanerozoic, Si deposition has largely been mediated by biology (Siever, 1992). Ocean geochemistry underwent major upheavals around the Precambrian/Cambrian boundary (Brennan et al., 2004; Cui et al., 2016) and into the Palaeozoic. A concomitant biotic upheaval at this time was the appearance of biomineralized hard parts of materials like calcium carbonate, calcium phosphate, and silica. The resulting evolutionary arms race led to a proliferation of skeletonized organisms, including siliceous radiolarians and sponges (Cohen, 2005; Knoll and Kotrc, 2015). The resolution of the conflict (Smith and Szathmáry, 1995) produced a proliferation of non-DSi users and some highly efficient DSi users leading to the extinction of inefficient DSi users. The initiation of a sedimentary flux of BSi with subsequent preservation in sediments would have continued the decrease in oceanic DSi concentrations, as evidenced by the lack of Phanerozoic abiotic cherts outside of unusual environments like hydrothermal waters (Maliva et al., 2005). Siever (1991) estimated that DSi concentrations at the start of the Phanerozoic were on the order of $1,000 \mu \mathrm{M}$, which is already depleted relative to amorphous Si solubility.

Racki and Cordey (2000) used concepts from punctuated equilibrium and proposed that all major reorganizations of marine biosilicfiers lead to stepdown decreases in DSi levels through geologic time. They proposed that the first major changes in oceanic DSi concentrations occurred much earlier in the Phanerozoic than postulated by Siever (1991) beginning at the Permian-Triassic boundary. Thereafter, a series of major reorganizations in biota that biosilicify occurred that induced rapid decreases in DSi especially with the evolution of diatoms (Racki and Cordey, 2000).

Establishing the extent and timing of the changes in the silica cycle due to evolutionary and paleo-ecology shifts in silica secreting biota is, however, a task that needs more work. In a systematic review of the literature Schubert et al. (1997) determined that a large bias exists in the early literature because poorly preserved specimens have been neglected as taxonomists required well-preserved material to do their work, skewing microfossil-based attempts at reconstructing the Si cycle. Kidder and Erwin (2001) made qualitative estimates of the relative importance of Si burial through the Phanerozoic and assumed that plankton would be more effective than benthic sponges at removing DSi from the ocean. They hypothesized that once radiolarians arrived on the scene, their relative contribution to BSi production quickly dwarfed that of siliceous sponges. They further hypothesized that diatoms have dominated the ocean Si cycle since the late Jurassic (Figure 1B). But in truth, the extent to which these putative changes in sponge and radiolarian abundance/distribution changed oceanic DSi concentrations (Schubert et al., 1997; Racki and Cordey, 2000; Kidder and Erwin, 2001), and the extent to which they were themselves influenced by reduced DSi availability are not really known.
One of the lines of evidence supporting a decline in the ocean DSi inventory in the early Phanerozoic is a change in the sedimentary facies associated with sponges in the geological record. Kidder and Tomescu (2016) derived a mid-Ordovician retreat in sponges from lagoonal depositional environments toward deeper shelf settings. The interpretation is of a radiolarian driven DSi depletion of the surface ocean. The link between sponge distributions and DSi stems from the implicit assumption that siliceous sponges are unable to thrive at low DSi (e.g., Maldonado et al., 1999; Ritterbush et al., 2015), although siliceous sponge reefs in the modern oceans are still forming in some areas despite the relatively low DSi concentrations $(10-40 \mu \mathrm{M})$ (Uriz, 2006; Chu and Leys, 2010; Maldonado et al., 2015). The modern day global distribution of sponges suggests that sponges are adapted to a great range of DSi conditions and the presence of sponges in the stratigraphic record must be treated cautiously (Alvarez et al., 2017).

Si biomineralization has been an important process for land plants over the course of their $>400$ My evolutionary history (Trembath-Reichert et al., 2015). On land the uptake of DSi and deposition by many vascular plants provides ecological, physiological, or structural benefits (Epstein, 1999), creating an active terrestrial Si cycle (Conley, 2002). The origin of terrestrial plants and the spread of rooted vascular plants to upland areas during the Devonian Period most likely had an important effect on many Earth processes (Lenton et al., 2012; though see Edwards et al., 2015). The activities of plants should increase the efficiency of continental weathering (Berner, 1997) through stimulated dissolution of bedrock (Schwartzman and Volk, 1989), thus enhancing the removal of atmospheric $\mathrm{CO}_{2}$ (Berner, 1990) until a new steady state is reached in weathering. A wide range of geochemical carbon models assume weathering rates to be proportional to $\mathrm{CO}_{2}$ fertilization of plant productivity, which acts as a key component of the silicate-weathering feedback (Pagani et al., 2009; Beerling et al., 2012). Similarly, plant functional trait evolution has been linked to stepwise changes in the long-term carbon cycle (e.g., Banwart et al., 2009).

The archaeplastid supergroup, to which land plants belong, is notable amongst eukaryotic supergroups for the lack of SIT or SIT-L transporters (Marron et al., 2016), despite widespread sequence data and the presence of several silicified taxa (such as horsetails, grasses, and the red alga Porphyra purpurea). Instead, Si uptake by land plants is performed by a combination of passive transmembrane channels and active Si effluxers (Ma and Yamaji, 2015). The active transporter is termed Lsi2 (low-silicon 2) (Ma et al., 2007). Lsi2-type genes are apparently ubiquitous in land plants, even in lineages which are not extensively silicified or which apparently lack Si-permeable transmembrane channels (Hodson et al., 2005; Trembath-Reichert et al., 2015; Marron et al., 2016). Importantly, Lsi2-type genes are found in the transcriptomes of both basal land plants and in the related charophyte green algae (see Table 1), while such sequences were not detected in more distantly related chlorophyte green algae (Marron et al., 2016). This strongly suggests that active $\mathrm{Si}$ transport is an ancient feature, and that Lsi2-type transporters predate the recruitment of NIPII-class transmembrane proteins 
TABLE 1 | Examples of Lsi2-type active Si transporters from across the Charophycae.

\begin{tabular}{|c|c|c|c|c|}
\hline Group & Sub-group & Species & Sequence ID & References \\
\hline \multirow[t]{2}{*}{ Charophyte algae } & Klebsormidales & Klebsormidium flaccidum & kfl00337_0090 & Hori and co-authors, 2014 \\
\hline & Zygnematales & Spirogyra pratensis & GBSM01008107.1 comp6609_c0_seq2 & Van de Poel et al., 2016 \\
\hline \multirow[t]{6}{*}{$\begin{array}{l}\text { Embryophytes } \\
\text { (land plants) }\end{array}$} & Liverworts & Marchantia polymorpha & Mapoly0153s0006.1 & $\begin{array}{l}\text { Sequence retrieved from } \\
\text { http://marchantia.info }\end{array}$ \\
\hline & Mosses & Physcomitrella patens & XP_001772790 & EMBL/Genbank database \\
\hline & Horsetails & Equisetum giganteum & cds.Locus_1866_Transcript_1_2_m.4165 & Vanneste et al., 2015 \\
\hline & "Gymnosperms" & Pinus monticola & GBQX01048264.1 & EMBL/Genbank database \\
\hline & Angiosperms (monocots) & Oryza sativa & ADH94038.1 & EMBL/Genbank database \\
\hline & Angiosperms (dicots) & Cucumis sativus & APT69295 & EMBL/Genbank database \\
\hline
\end{tabular}

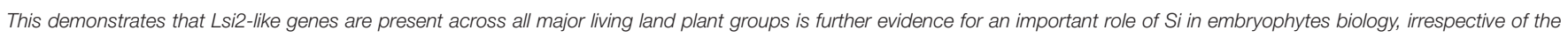

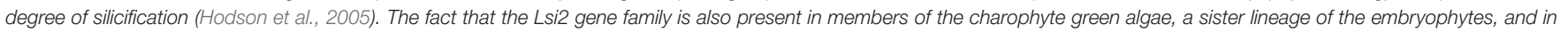
basal land plant groups (liverworts and mosses) means that the earliest land plants also possessed such transporters.

as passive Si channels (Trembath-Reichert et al., 2015). While Si may play a wider role in land plant metabolism (e.g., Markovich et al., 2017), the primary function of active Si transport is presumably to enhance DSi uptake rates into the transpiration stream and toward sites of BSi precipitation. It is therefore reasonable to assume that even the earliest terrestrial plants could have played a role in the global Si cycle.

The feedbacks through enhanced weathering would also alter the flux of DSi from the continents and thus potentially alter oceanic DSi availability (Conley and Carey, 2015). A key issue to resolve is the extent to which global average river inputs of DSi could have changed due to plant-stimulated weathering (Moulton and Berner, 1988) for a given atmospheric concentration of $\mathrm{pCO}_{2}$. Although the enhancement of silicate weathering by plants is expected to transiently increase the supply of DSi to the oceans, available data do not show an increase in numbers of chert deposits with the rise of plants (Kidder and Erwin, 2001). What has not been previously considered in the effect of plants on weathering, is the evolution of plants that accumulate phytolith BSi (Hodson et al., 2005), also allowing for more BSi accumulation on the continents (Struyf and Conley, 2012). However, phytolith BSi accumulated in soils on land is not an infinite sink, with the modern inventory comprising ca. $8.25 \times 10^{15} \mathrm{~mol} \mathrm{Si}$ (Laruelle et al., 2009), and is dwarfed by the magnitude of DSi inventory in the oceans, with the total modern day ocean Si inventory estimated to be $112 \times 10^{15}$ mol (Gouretski and Koltermann, 2004), and was presumably an even smaller fraction than in the Paleozoic-Mesozoic ocean. Quirk et al. (2015) have challenged the suggestion that early land plants significantly enhanced total weathering arguing that the rise of rooted vascular plants and mycorrhizal fungi caused an increase in the production of pedogenic clays retaining $\mathrm{Si}$ on the continents, and thus lessening the impact of DSi transport to the global oceans.

Although Kidder and Erwin (2001) argued that there were large-scale changes in radiolarian and sponge abundances during the Paleozoic (Figure 1B), Siever (1991) suggested that the geologic record does not support the occurrence of widespread siliceous sediments and thus did not affect DSi in the global oceans (Figure 1A). More importantly, Maliva et al. (1989) argue that nodular chert formation predominated in the Paleozoic and was the result of DSi diffusion into sediments from the essentially infinite reservoir in the overlying water because there was insufficient biogenic precipitation. Kidder and Tomescu (2016) suggested that the evolution of the oceanic Si cycle through the early Paleozoic was a dynamic progression of biogeochemical adjustments driven by biological and earth system changes, which changed DSi availability driving the distribution of sponges and radiolarians in the ocean. Based on first principles (Equation 1), early biosilicification by radiolarians and sponges during the Paleozoic and subsequent deposition and burial of BSi should have resulted in global deceases in oceanic DSi availability because of the greater preservation efficiency at high oceanic DSi. Essentially, a small increase in biosiliceous productivity would be expected to have a disproportionate effect on the total DSi inventory. Declines in DSi would occur until the sinks were balanced by the sources (De La Rocha and Bickle, 2005). Our hypothesis is that DSi concentrations were reduced even further from saturating conditions at the start of the Phanerozoic, but biosilicification of sponges and radiolarians reduced DSi concentrations to an even lower level than previously appreciated.

\section{TRANSITION TO AN OCEAN DOMINATED BY BIOSILICIFICATION}

The narrative outlined by Siever (1991) envisages a transition, starting around the mid-Cretaceous and ending by the late Paleogene (Figure 1A), from a DSi-replete (ca. 1,000 $\mu \mathrm{M}$ ) surface ocean, to DSi-depleted conditions broadly similar to the modern day (Maliva et al., 1989; Siever, 1991). This is period of Earth history with the most available data, thanks in large part to the efforts of the ocean drilling community over the past decades. Several lines of evidence are available to guide interpretation of late Mesozoic-Cenozoic Si cycling. The 
Mesozoic saw huge changes in marine ecosystems compared to Palaeozoic seas (Knoll and Follows, 2016), including the appearance and radiation of many new phytoplankton groups such as dinoflagellates, diatoms, coccolithophorid haptophytes, and chrysophytes (Knoll, 2003; Katz et al., 2004; Sims et al., 2006). Diatoms, in particular, flourished during the Cenozoic, which has been interpreted to have caused a drawdown of DSi (Racki and Cordey, 2000). Fossil evidence also demonstrates the decline of siliceous sponge reefs in the late Mesozoic (Kidder and Tomescu, 2016). Muttoni and Kent (2007) clearly demonstrate an increase in chert intervals in DSDP and ODP sites during the early Eocene primarily from radiolarian deposition, although modeling and mass-balance principles clearly show that inputs and outputs are generally tightly coupled such that enhanced BSi burial likely reflects changes in DSi inputs (Yool and Tyrrell, 2005). Silicoflagellates (dictyochophyte), diatoms, and radiolarian microfossils (Lazarus et al., 2009; Finkel and Kotrc, 2010; van Tol et al., 2012), all show a trend towards more lightly silicified structures and more efficient DSi use through this phase.

The Cenozoic rise in diatom diversity has long been related to a concurrent decline in radiolarian test silicification (Harper and Knoll, 1975). Gradually decreasing Cenozoic radiolarian test weight suggests that competition for DSi resulted in coevolution between radiolaria and marine diatoms. More sophisticated attempts to answer the question include Lazarus et al. (2009). However, they determined that trends in shell size and silicification are statistically insignificant and are not correlated with each other. They concluded that there is no universal driver changing cell size in Cenozoic marine plankton. Conventionally, diatom diversification describes a steep, monotonic rise (Rabosky and Sorhannus, 2009), a view also questioned due to sampling bias (Lazarus et al., 2014). In low latitudes, increasing Cenozoic export of DSi to deep waters by diatoms and decreasing nutrient upwelling from increased water column stratification have created modern DSi-poor surface waters. Here, radiolarian silicification decreases significantly. The radiolarian decline in silicification could result from either macroevolutionary processes operating above the species level (punctuated equilibria) or anagenetic changes within lineages (Kotrc and Knoll, 2015). This change in the degree of silicification is less apparent at higher latitudes, most likely reflecting an ample supply of DSi via upwelling.

The minimum and maximum sizes of the diatom frustule have expanded in concert with increasing species diversity, although the mean area of the diatom frustule has been highly correlated with oceanic temperature gradients consistent with the hypothesis that climatically induced changes in oceanic mixing have altered nutrient availability in the euphotic zone and driven macroevolutionary shifts in the size of marine pelagic diatoms through the Cenozoic (Finkel et al., 2005). Fossil evidence of diatom biosilicification is present in the geologic record from ca. $190 \mathrm{Ma}$ (Sims et al., 2006), yet molecular clock analyses indicate that diatoms originated closer to the Permian-Triassic boundary $250 \mathrm{Ma}$ (Medlin et al., 1996; Graham and Wilcox, 2000; Sims et al., 2006), and that the diatom stem lineage may have even earlier origins in the mid-Paleozoic (Brown and Sorhannus, 2010).
Various hypotheses have been made as to why the diversification and increase in the global biomass of marine diatoms occurred only during the last $40 \mathrm{My}$ of Earth's history and why diatoms were not successful earlier. Raven and Waite (2004) hypothesize that silicification could have evolved later in the evolutionary history of diatoms and would be an explanation for the lack of diatoms in the fossil record, although this does not agree with the evidence for an ancient evolution of SITs in this lineage (Marron et al., 2016). It may be the case that the ancestral diatoms have been partially silicified with plates rather than complete frustules, similar to the modern Parmales, the sister lineage of diatoms (Yamada et al., 2014). In this scenario the earliest diatoms may simply have gone unrecognized in the fossil record. The rapid rise of diatoms in the Cenozoic has also been attributed to the impact of orogeny on weathering (Misra and Froelich, 2012) with periods of enhanced continental weathering fluxes and increased DSi input to the oceans (Cermeño et al., 2015).

The rapid drawdown of DSi during the Cenozoic by diatoms attests to their competitive ability to efficiently remove DSi to low levels in the water column. Diatoms show a high degree of SIT diversification with an efficient suite of specialized transporters and uptake regimes allowing them to dominate DSi utilization amongst marine silicifiers (Thamatrakoln and Hildebrand, 2008; Durkin et al., 2016; Marron et al., 2016). Diatoms have an obligate requirement for $\mathrm{Si}$ to complete their life cycle and so cannot avoid competing for Si (Hildebrand, 2000). This combined with the other advantages unrelated to Si (e.g., nutrient acquisition and storage, light harvesting, bloom formation), must have produced trophic interactions that did not occur in Palaeozoic oceans, making the appearance of diatoms a game changer. Therefore, we hypothesize that diatoms had an impact on oceanic DSi concentrations much earlier in the geological record than previously thought.

Recently, Fontorbe et al. (2016) used $\delta^{30} \mathrm{Si}$ from sponge spicules and radiolarian tests to derive the first long term empirical reconstruction of ocean DSi concentrations in the North Atlantic during the Paleocene and Eocene. Using a calibrated relationship between spicule $\delta^{30} \mathrm{Si}$ and sponge $\mathrm{Si}$ isotope fractionation (Wille et al., 2010; Hendry and Robinson, 2012), they show that from 60 to 30 Ma DSi concentrations in the North Atlantic were consistently low, meaning that the transition to a low DSi ocean had to have begun prior to the Early Cenozoic (Figure 4A). Subsequent cores from the Pacific Ocean, showed (Figure 4B) that deep water DSi concentrations were also lower prior to $37 \mathrm{Ma}$ (Fontorbe et al., 2017). The shift in radiolarian $\delta^{30} \mathrm{Si}$ was interpreted as a consequence of changes in the $\delta^{30} \mathrm{Si}$ of DSi sourced to the region through changing ocean circulation. The decrease in sponge $\delta^{30} \mathrm{Si}$ is interpreted as a transition from low DSi concentrations to higher DSi concentrations, most likely related to the shift toward a solely Southern Ocean source of deep-water in the Pacific during the Paleogene consistent with results from ocean circulation tracers including neodymium isotopes and carbon isotopes (Fontorbe et al., 2017). Diatom and spicule $\delta^{30} \mathrm{Si}$ records from the Southern Ocean are consistent with the establishment of a near modern system, with a protoAntarctic Circumpolar Current (ACC), a full deep water pathway 

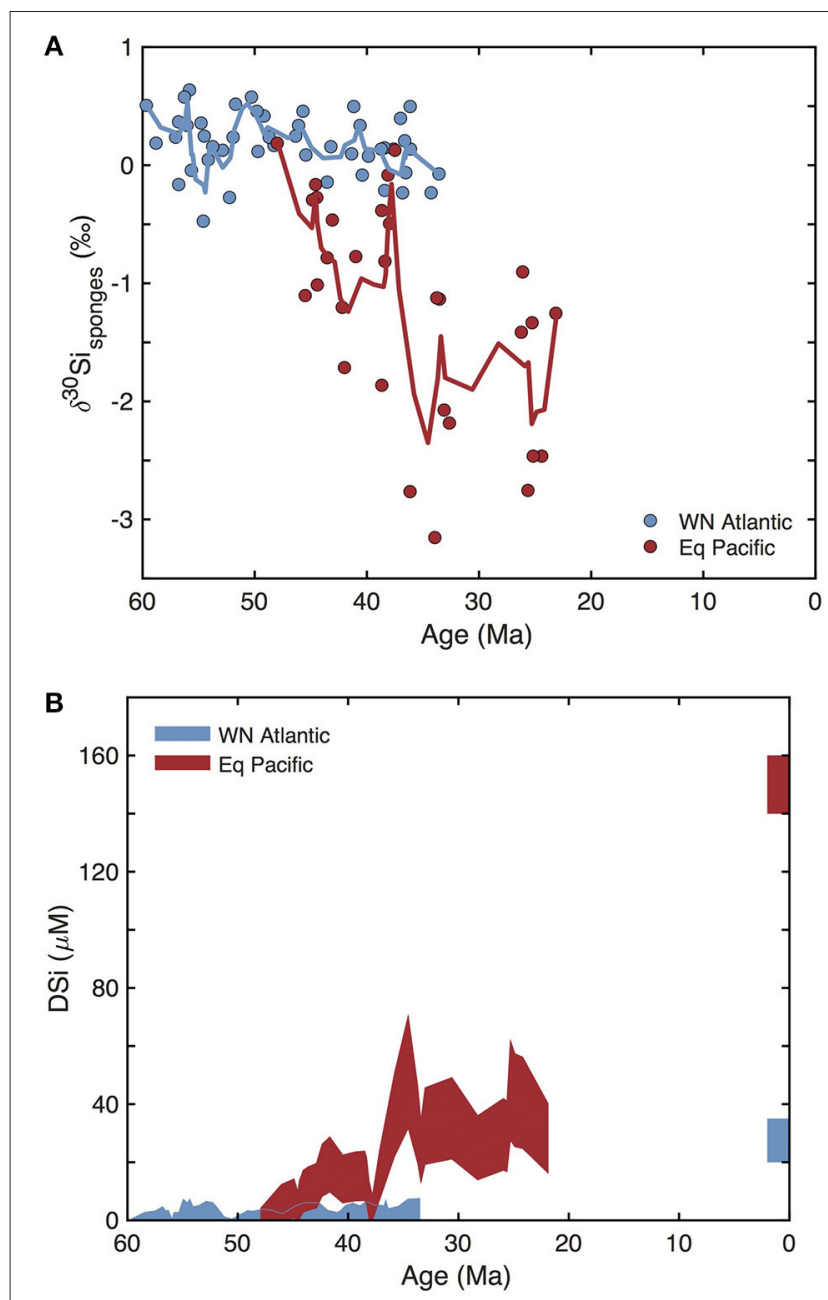

FIGURE 4 | (A) The range of $\delta^{30} \mathrm{Si}$ of sponges from deep-sea drilling cores (Fontorbe et al., 2016, 2017). (B) The range of DSi concentrations in the Western North Atlantic (blue) and in the Equatorial Pacific (red) reconstructed from the $\delta^{30} \mathrm{Si}$ of sponges and radiolarians from deep-sea drilling cores (Fontorbe et al., 2016, 2017). The blue and red bars for present time represent the modern DSi concentration in the bottom waters of both ocean basins.

through the Tasman Sea and Drake Passage, and associated high-latitude upwelling at the Eocene-Oligocene boundary (Egan et al., 2013). The emerging tools of Si stable isotope tracers (De La Rocha, 2002; Sutton et al., in review) have demonstrated that very low oceanic DSi concentrations may have occurred tens of millions of years before the time period envisioned by Siever (1991) and others for the drawdown of DSi by diatom biosilicification. We hypothesize that if such a global decrease in oceanic DSi concentrations occurred, it must predate $60 \mathrm{Ma}$ and perhaps begin with the appearance of diatoms.

Although diatoms originated in the early Mesozoic (Medlin et al., 1996; Graham and Wilcox, 2000; Sims et al., 2006), peak diversification occurred in the Cenozoic (Rabosky and Sorhannus, 2009). Several rapid evolutionary turnovers in the diatom species composition have been observed at the Paleocene-Eocene boundary, and at the Eocene-Oligocene boundary. Here, we posit that rather than driving the drawdown in surface DSi concentration, the diversification of diatom species observed during the Cenozoic may have instead resulted from several external factors. Firstly, this diversification might have resulted from a change in the global distribution of DSi. The basinal distribution of DSi is dominated by ocean circulation (de Souza et al., 2014) with the AAC playing a key role in the dynamic of ocean circulation and nutrient distribution, most likely since the Eocene-Oligocene boundary around $34 \mathrm{Ma}$. The upwelling associated with the strong ACC would have promoted the growth of high-latitude diatom populations, which enhanced DSi uptake. Secondly, diatom diversification could have resulted from a change in the DSi delivery from land to ocean via increased transport of weathering products. Based on Li isotopes, Misra and Froelich (2012) argued for increasing weathering rates over the Cenozoic. Recently, this increase in the fluxes of weathering products has been invoked to explain the diatom diversification over the Cenozoic (Cermeño et al., 2015), again, drawing down DSi concentrations to the low levels that we suggest were experienced since the Mesozoic.

\section{OCEANIC DSI DURING THE QUATERNARY}

The modern ocean distribution of DSi is primarily controlled by the general ocean circulation and dissolution of BSi formed in the upper water column (de Souza et al., 2014). The general pattern consists of surface waters with low DSi concentrations due to the efficient uptake by diatoms (and to a lesser degree radiolarians, silicoflagellates and other silicifying organisms). Concentrations increase with depth via progressive dissolution of diatom frustules and radiolarian tests precipitated in the upper water column during their sinking (Tréguer and De La Rocha, 2013; Frings et al., 2016). An inter-basinal gradient also exists, related to the overturning circulation. Today, deepwaters formed in the North Atlantic from surface waters are DSi depleted due to the efficient uptake of DSi by diatoms. These newly formed bottom waters get progressively enriched in DSi as they are transported southward toward lower latitudes, ultimately ventilating in the Southern Ocean or the North Pacific. This general circulation pattern results in a bottom water basinal DSi concentration gradient with North Atlantic waters having the lowest levels of DSi (typically 20-30 $\mathrm{MM}$ ) and the North Pacific waters being the most concentrated (up to $200 \mu \mathrm{M}$ ). In the Southern Ocean, the DSi increases polewards and with depth, as a result of remineralization, the mixing of water masses and the sloping isopycnal gradient resulting from the strong ACC (Pollard et al., 2002). Low utilization of DSi relative to other nutrients by diatoms in the iron-limited waters near the Polar Front, together with strong winter convection, results in the export of waters with high DSi:N (or P) ratios in the Antarctic Intermediate Waters (AAIW) into the Atlantic and the Pacific (Sarmiento et al., 2004).

Global changes in the total supply of DSi to the ocean have likely occurred throughout the Quaternary. Changes in weathering processes, as a result of the waxing and waning of ice-sheets during glacial cycles, and climatically-driven changes 
in biological production could shift oceanic DSi over timescales equivalent to the residence time of $\mathrm{Si}$ in the ocean $(\sim 10$ 15 ky; Georg et al., 2009; Frings et al., 2016). More regional changes in DSi distribution could be triggered on millennial to centennial timescales through changes in the configuration of oceanic circulation cells, wind-driven upwelling systems (Hendry et al., 2016), and biological changes in the regions of deepwater formation (Brzezinski et al., 2002; Bradtmiller et al., 2009; Meckler et al., 2013; Hendry and Brzezinski, 2014).

An implicit assumption in the global $\mathrm{Si}$ mass-balance remains that there exists a steady-state. At the moment, however, it is more likely that the global Si cycle, at least in the short term, is out of balance in response to changing inputs during the Anthropocene. Human activities such as deforestation, eutrophication, agriculture, and damming have altered weathering rates, amounts of terrestrial BSi production, and the amount of amorphous Si retained and/or released from soils and freshwater systems (Struyf et al., 2010). Our recent work demonstrates the gradual aggradation or depletion of the amorphous Si pool held in continental soils (Barão et al., 2015) and aquatic sediments (Frings et al., 2014) in response to changing environmental forcings (Struyf and Conley, 2012). Our emerging understanding is that DSi inputs from the continents (Frings et al., 2016) have potentially altered the magnitude and isotopic composition to an extent great enough to impact wholeocean isotopic signatures on the timescale of Quaternary glacial cycles (Bernard et al., 2010). This suggests that the continental Si cycle should be seen as a potential contributory factor to any variability observed in oceanic DSi (Conley, 2002; Street-Perrott and Barker, 2008; Carey and Fulweiler, 2012).

\section{SYNTHESIS: RECONSTRUCTION OF OCEANIC DSI CONCENTRATIONS IN DEEP TIME}

The assumptions regarding the evolution of the biogeochemical cycle of $\mathrm{Si}$ in the oceans need to be reexamined. The two critical assumptions made by Maliva et al. (1989) regarding secular changes in the distribution of cherts was (1) that biological participation in the Si cycle began in the Phanerozoic with the advent of widespread eukaryotic skeletal biosilicification and (2) that based on the modern oceans, sponges and radiolarians in the past contributed to a lesser degree than diatoms in modifying oceanic DSi concentrations. The discovery by Baines et al. (2012) that the cyanobacterium Synechococcus was capable of accumulating significant quantities of Si and that bacterialtype SIT-L sequences were present in the prokaryotic size fraction of the Tara Oceans environmental metagenomic sequencing datasets (Sunagawa et al., 2015; Marron et al., 2016) disproves the first hypothesis, although the actual quantitative contribution of biosilicification by prokaryotes to the global $\mathrm{Si}$ cycle in the present and the past is currently unknown. Secondly, the role of radiolarians and sponges in modifying oceanic DSi concentrations has been questioned (Kidder and Tomescu, 2016) with shifts in the global distribution of radiolarians and sponges preserved in sediments related to changes in oceanic DSi concentrations. Finally, Fontorbe et al. (2017) suggest that the superior competitive ability of diatoms for DSi relative to other siliceous plankton such as radiolarians, likely rapidly reduced DSi concentrations early in their evolution as they increased in abundance to the low levels of DSi observed in the oceans today (Tréguer and De La Rocha, 2013). These changes occurred due to the innovation of more sophisticated and versatile DSi uptake mechanisms especially by diatoms (Thamatrakoln and Hildebrand, 2008; Durkin et al., 2016; Marron et al., 2016).

We present a third narrative regarding the evolution of the oceanic Si cycle (Figure 5). Significant biological and geological events occurred throughout geologic time that affected the global oceanic Si cycle (Figure 6). Our narrative suggests that Archean organisms possessed and utilized Di transporting proteins and decreases in DSi occurred already in the Precambrian reflecting first the evolution of cyanobacteria ca. 3,000 Ma (Dvorák et al., 2014) lowering DSi concentrations from saturation and contributing to the deposition of BSi. The deposition of BIFs (Fischer and Knoll, 2009) drove DSi in the surface oceans to $500-1,000 \mu \mathrm{M}$ (Zheng et al., 2016) through the formation of Fe-Si gels. After the great oxidation event (Kump, 2008) DSi concentrations rapidly increased as the formation of BIFs were reduced and DSi concentrations were again controlled primarily by biological Si homeostasis mechanisms and cyanobacteria $\mathrm{Si}$ accumulation. We place DSi in the surface oceans below saturation because of biosilicification, although the deposition by prokaryotes was probably not sufficient to reduce wholeocean DSi and is supported by chert deposition (Maliva et al., 1989, 2005). DSi was likely reduced in the Late Proterozoic with the evolution of significant eukaryotic biosilicification across multiple taxa (Knoll, 2017), including early siliceous sponges. This biomineralization revolution would have further reduced DSi sufficiently below saturation to account for the widespread, independent losses of silicon transporters postulated in Marron et al. (2016). The next significant DSi drop occurred in the lower to early Middle Ordovician with increased usage by sponges and radiolarians (Kidder and Tomescu, 2016). Finally, it is the appearance and subsequent proliferation of biosilicifying phytoplankton, most importantly the diatoms with their superior ability to reduce DSi concentrations to the low levels observed in the global oceans today (Tréguer and De La Rocha, 2013).

In today's oceans, DSi concentrations are largely biologically controlled, namely that BSi production through the uptake of DSi by fairly high affinity silica transporters and the biological templates guiding deposition mean that high rates of BSi production can be sustained at lower environmental concentrations of DSi. This allows for the same amount of material to be exported at lower DSi concentrations than is possible by abiotic control only or by a previously existing set of silica biomineralizers.

The response in changes in DSi is faster at high DSi concentrations due to a proclivity of preservation over dissolution of BSi (Equation 1; Van Cappellen et al., 2002). In addition, macroevolution can occur over relative short periods of geological time as a result of competitive exclusion. For example, Kidder and Tomescu (2016) suggest that the shifts between the loci of sponges from shallow to basinal 


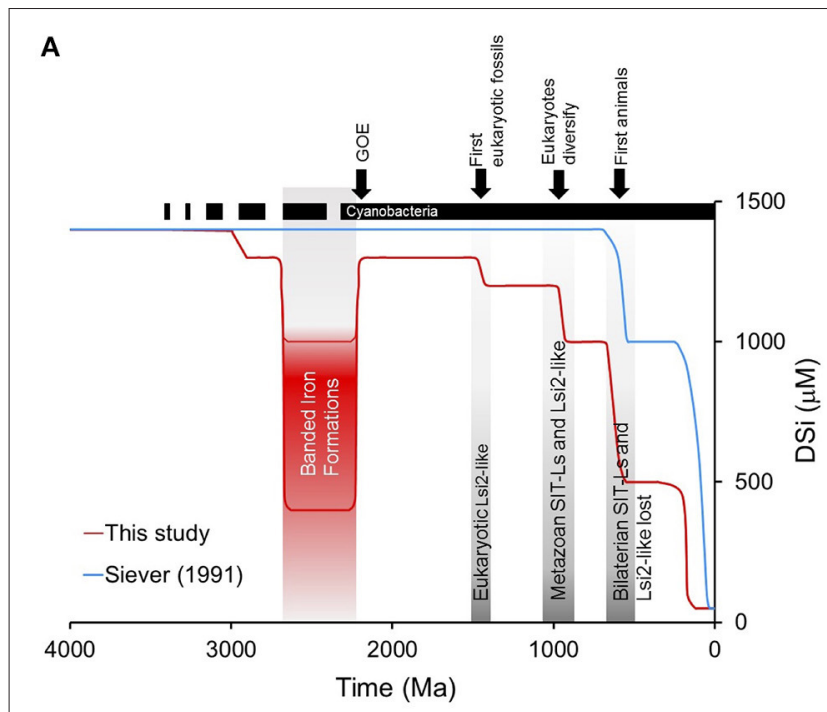

B

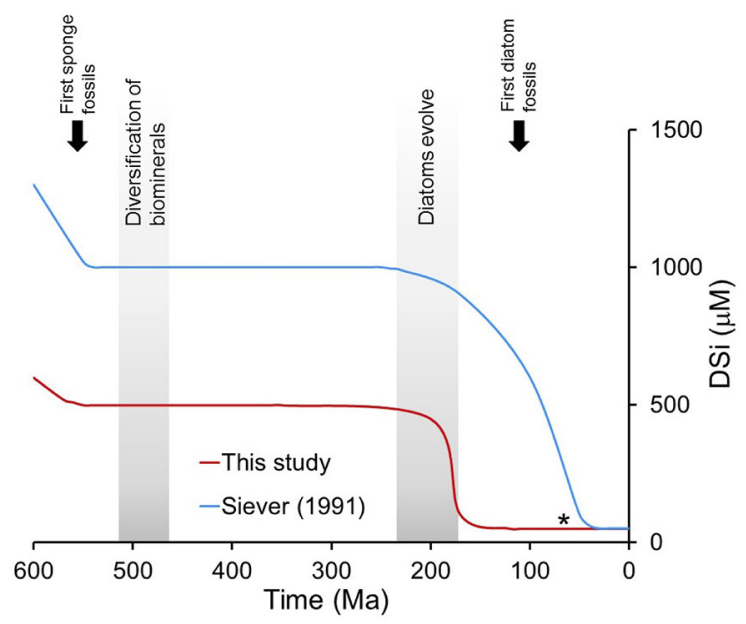

* - Isotopic evidence for low oceanic Si

FIGURE 5 | The evolution of the oceanic Si cycle through geologic time envisioned by Siever (1991) (blue line) together with our narrative for reductions in DSi primarily through biosilicification (red line). (A) From the early Precambrian to the present with the major biological and geological events. The dotted line for cyanobacteria reflects the uncertainty in the timing of its evolution in the geological record. (B) DSi from the latest Precambrian to the present.

environments may have taken approximately 2-14 My in the late Lower to early Middle Ordovician as a result of DSi uptake by radiolarians. Futhermore, Ritterbush et al. (2015) has estimated that oceanic DSi changes could occur in timescales of 100-500 ky with an increase in DSi flux at the Jurassic-Triassic boundary as a consequence of the increased weathering of Central Atlantic Magmatic Province basalts. Models utilizing the sediment record are needed to constrain the rapidity of the response of sediment BSi burial to changes in the temporal distribution of DSi inputs to the oceans (Yool and Tyrrell, 2005; Lenton and Daines, 2017).

\section{CHALLENGES TO EXISTING KNOWLEDGE}

\section{An Imperfect Geological Record}

The lack of fossils to verify or falsify our hypothesis can simply be an artifact of a sparse geological record. There remains great potential for new discoveries with increased sampling and more focused investigations for the fossil remains of more diverse silicifying groups. However, a record of the rapid declines in DSi that occurred must be buried in ocean sediments most of which have been subducted and recycled by the movement of the continents. Whether or not the Siever (1991) narrative or the one presented here are possible, the question remains: where are the massive deposits of BSi that must have occurred with rapid drawdowns in ocean DSi concentrations? In addition, are these deposits resolvable by bulk measurements or isotopically, and can they be attributable to transient decreases in the ocean inventory of $\mathrm{Si}$ on the basis of mass-balance calculations?

\section{Formation of Chert Deposits}

High BSi sediments from the deposition of sponges, radiolarians and/or diatoms, which are precursors to chert formation, still occur today e.g., in places where productivity is high such as upwelling areas. The interpretation that DSi saturation occurred in bottom waters above chert nodule formation has been questioned (Ritterbush et al., 2015) with Moore's (2008) alternative explanation for chert formation as mobilization of amorphous hydrothermal deposits in deeper sediments, which removes chert nodules as indicators of DSi concentration through time. This brings into question an important tenant by Maliva et al. (1989) regarding chert deposition reflecting DSi concentration in the water column.

\section{Does Sponge Abundance Reflect DSi?}

Maldonado et al. (1999) suggested declines in reef building sponges occurred at the Cretaceous-Tertiary boundary because of DSi limitation as diatoms evolved. However, highly siliceous sponge reefs are still forming in selected areas of the modern oceans despite the relatively low DSi concentrations (Uriz, 2006; Chu and Leys, 2010; Maldonado et al., 2015). There are certainly other factors, such as food availability and ocean temperature (Kahn et al., 2012) that control the abundance and biosilicification of sponges (Alvarez et al., 2017).

\section{Biosilicification Is Not the Only Factor}

The first order interpretation is that DSi controls the morphology and biosilicification of organisms (Leadbeater and Jones, 1984; Finkel et al., 2010; Yamada et al., 2014). Yet, additional evolutionary selective pressures on the morphology of the siliceous diatom frustule have been identified, including changes in growth-limiting nutrients other than $\mathrm{Si}$ (Marchetti and Cassar, 2009), $\mathrm{CO}_{2}$ (Milligan and Morel, 2002), and predation (Pondaven et al., 2007) have shaped the morphology of the frustule over geologic time (Finkel and Kotrc, 2010). In addition, Si transporter (SITs, SIT-Ls and Lsi2-like) genes are found in many eukaryotes that are not major biosilicifiers today (Marron et al., 2016), yet in some organisms (e.g., calcareous haptophytes) $\mathrm{Si}$ is required in trace amounts (Durak et al., 2016). Are there other factors that are contributing to changes in oceanic DSi in deep time? 


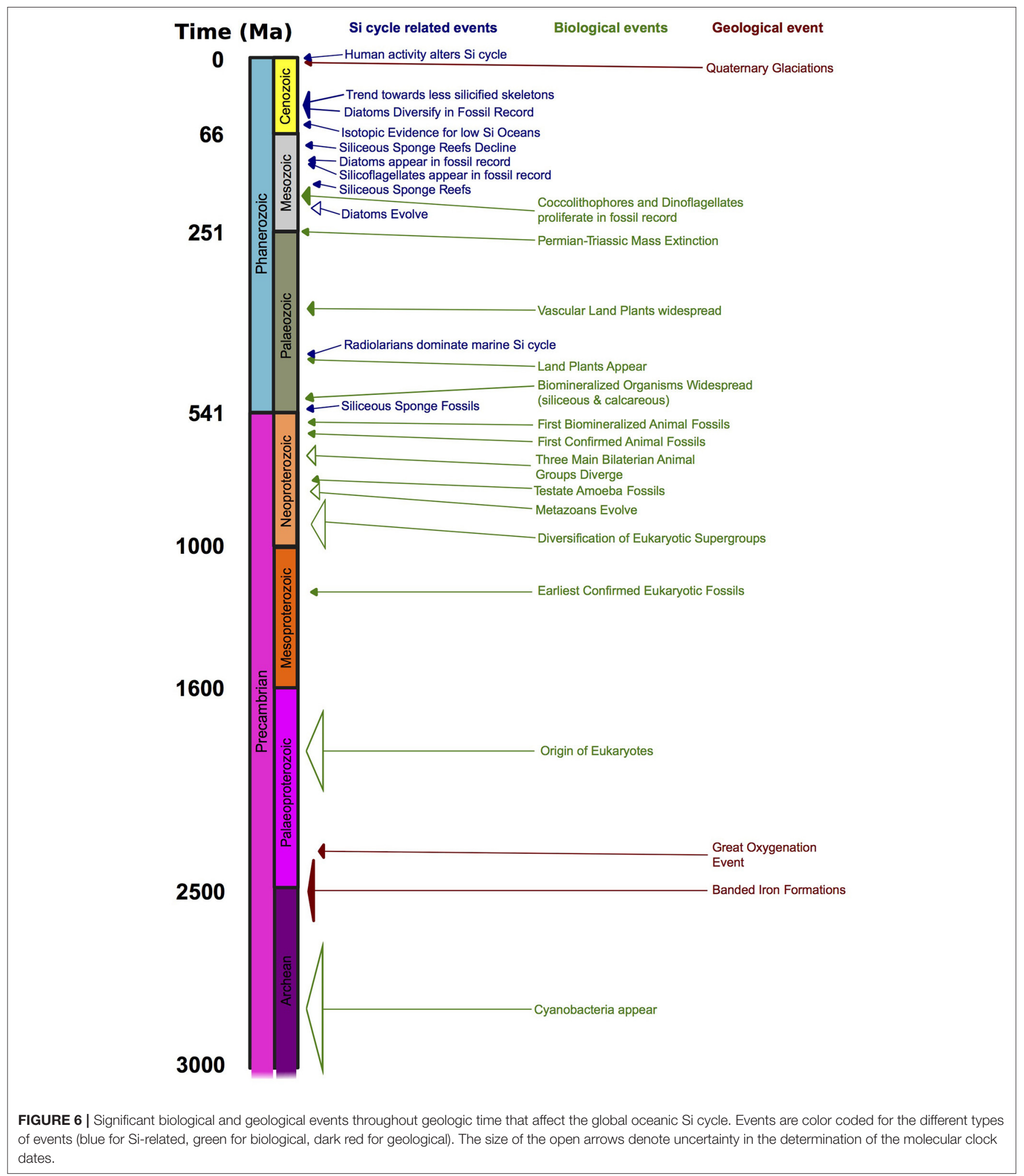

\section{Temporal Sensitivity of Marine DSi} Concentration

All narratives describe changes in DSi as a linear process from high to low DSi concentrations with the evolution of specialized mechanisms for DSi uptake and biosilicification. A change in DSi fluxes to the ocean, can be caused for example by either changes in hydrothermal fluxes or by changes in continental weathering. Further investigations must be done to unravel the 
amplitude and duration of such events that impact global DSi concentrations. In addition, there can be short-term changes in DSi fluxes (Frings et al., 2016) as well as fluctuations in the shortterm production of biosilicifying organisms due to changes in the sources of DSi. For example, Ritterbush et al. (2015) argue that the Early Jurassic siliceous sponge takeover was likely permitted by an increased DSi flux as a consequence of weathering of the Central Atlantic Magmatic Province (CAMP) basalts. Does the volcanism associated with the formation of large igneous provinces (Kidder and Worsley, 2010) allow for changes in oceanic DSi concentrations or are inputs continuously balanced by burial?

\section{CONCLUSION}

Combining evidence from many different fields, e.g., biogeochemistry (Tréguer and De La Rocha, 2013), the study of the geological record (Maliva et al., 2005; Fischer and Knoll, 2009; Kidder and Tomescu, 2016), and the emerging field of geogenomics (Baker et al., 2014; Marron et al., 2016), we have identified changes in seawater DSi geochemistry by biosilicification (Figure 5). The first biological impacts on the $\mathrm{Si}$ cycle were likely due to the evolution of silicon homeostasis or detoxification mechanisms in the Proterozoic. We hypothesize that further decreases in DSi occurred prior to the start of the Phanerozoic with the evolution of widespread, large-scale skeletal biosilicification. DSi concentrations continued to be reduced by biomineralization and burial of BSi through deep time. Finally, we further hypothesize that the evolution of diatoms leads to a low DSi ocean already by the middle Mesozoic.

Our analysis suggests that the oceans have probably experienced lower DSi concentrations than previously appreciated (Siever, 1991). Our results challenge the Maliva

\section{REFERENCES}

Abraham, K., Hofmann, A., Foley, S. F., Cardinal, D., Harris, C., Barth, M. G., et al. (2011). Coupled silicon-oxygen isotope fractionation traces Archaean silicification. Earth Planet. Sci. Lett. 301, 222-230. doi: 10.1016/j.epsl.2010.11.002

Alvarez, B., Frings, P. J., Clymans, W., Fontorbe, G., and Conley, D. J. (2017). Assessing the potential of sponges (Porifera) as indicators of ocean dissolved Si concentrations. Front. Mar. Sci. 4:373. doi: 10.3389/fmars.2017.00373

André, L., Cardinal, D., Alleman, L. Y., and Moorbath, S. (2006). Silicon isotopes in $\sim 3.8 \mathrm{Ga}$ West Greenland rocks as clues to the Eoarchaean supracrustal Si cycle. Earth Planet. Sci. Lett. 245, 162-173. doi: 10.1016/j.epsl.2006.02.046

Antcliffe, J. B., Callow, R. H. T., and Brasier, M. D. (2014). Giving the early fossil record of sponges a squeeze. Biol. Rev. 89, 972-1004. doi: 10.1111/brv.12090

Baines, S. B., Twining, B. S., Brzezinski, M. A., Krause, J. W., Vogt, S., Assael, D., et al. (2012). Significant silicon accumulation by marine pico-cyanobacteria. Nat. Geosci. 5, 886-891. doi: 10.1038/ngeo1641

Baker, P. A., Fritz, S. C., Dick, C. W., Eckert, A. J., Horton, B. K., Manzoni, S., et al. (2014). The emerging field of geogenomics: constraining geological problems with genetic data. Earth Sci. Rev. 135, 38-47. doi: 10.1016/j.earscirev.2014.04.001

Banwart, S. A., Berg, A., and Beerling, D. J. (2009). Process-based modeling of silicate mineral weathering responses to increasing atmospheric $\mathrm{CO}_{2}$ and climate change. Glob. Biogeochem. Cycles 23:GB4013. doi: 10.1029/2008GB003243 et al. $(1989,2005)$ and the Siever $(1991,1992)$ framework and these results are contrary to what is currently believed. In addition, our analysis necessitates a revision of the singular role of DSi in driving the evolution of biosilicifying organisms in both marine and terrestrial systems, and the controls on global Si geochemistry.

It should be noted that the formation of Si-rich precipitates would also impact cycling of other elements especially in the Precambrian oceans, including iron, trace metals and phosphorus (e.g., Konhauser et al., 2007; Jones et al., 2015). In addition, the rise to ecological prominence of the diatoms is a relevant landmark in the history of the Earth system with a probable increase in the strength and efficiency of the biological pump and its impact on C (Renaudie, 2016). Therefore, the study of secular changes in the Si cycle bears on our general understanding of geochemical cycles in marine systems.

\section{AUTHOR CONTRIBUTIONS}

The manuscript was envisioned by DC. All authors participated in the discussion, writing and editing of the manuscript.

\section{ACKNOWLEDGMENTS}

This work was funded by a grant from the Knut and Alice Wallenberg Foundation and from the Swedish Research Council to DC. KH was funded by Royal Society grant \#UF120084. AM was funded by a Wellcome Trust Senior Investigator Award to Raymond E. Goldstein, DAMTP, University of Cambridge. All appropriate permissions have been obtained from the copyright holders of any work that has been reproduced in the manuscript. We gratefully thank Daniel Brooks, Jack Middelburg, and Patricia Sánchez-Baracaldo for helpful comments and two reviewers.
Barão, L., Vandevenne, F., Clymans, W., Frings, P., Ragueneau, O., Meire, P., et al. (2015). Alkaline-extractable silicon from land to ocean: a challenge for biogenic silicon determination. Limnol. Oceanogr. Methods 13, 329-344. doi: 10.1002/lom3.10028

Beerling, D. J., Taylor, L. L., Bradshaw, C. D. C., Lunt, D. J., Valdes, P. J., Banwart, S. A., et al. (2012). Ecosystem $\mathrm{CO}_{2}$ starvation and terrestrial silicate weathering: mechanisms and global-scale quantification during the late Miocene. J. Ecol. 100, 31-41. doi: 10.1111/j.1365-2745.2011.01905.x

Bernard, C. Y., Laruelle, G. G., Slomp, C. P., and Heinze, C. (2010). Impact of changes in river fluxes of silica on the global marine silicon cycle: a model comparison. Biogeosciences 7, 441-453. doi: 10.5194/bg-7-441-2010

Berner, R. A. (1990). Atmospheric carbon dioxide levels over Phanerozoic time. Science 249, 1382-1386. doi: 10.1126/science.249.4975.1382

Berner, R. A. (1997). The rise of plants and their effect on weathering and atmospheric $\mathrm{CO}_{2}$. Science 276, 544-546. doi: 10.1126/science.276.53 12.544

Bertolino, M., Cattaneo-Vietti, R., Pansini, M., Santini, C., and Giorgio Bavestrello, G. (2017). Siliceous sponge spicule dissolution: in field experimental evidences from temperate and tropical waters. Estuar. Coast. Shelf Sci. 184, 46-53. doi: 10.1016/j.ecss.2016.10.044

Bidle, K. D., and Azam, F. (1999). Accelerated dissolution of diatom silica by marine bacterial assemblages. Nature 397, 508-512. doi: 10.1038/17351

Bidle, K. D., Manganelli, M., and Azam, F. (2002). Regulation of oceanic silicon and carbon preservation by temperature control on bacteria. Science 298, 1980-1984. doi: 10.1126/science. 1076076 
Bradtmiller, L. I., Anderson, R. F., Fleisher, M. Q., and Burckle, L. H. (2009). Comparing glacial and Holocene opal fluxes in the Pacific sector of the Southern Ocean. Paleoceanography 24:PA2214. doi: 10.1029/2008PA001693

Braterman, P. S., Cairns-Smith, A. G., and Sloper, R. W. (1983). Photo-oxidation of hydrate $\mathrm{Fe}^{+3}$ - Significance for banded iron formation. Nature 303, 163-164. doi: $10.1038 / 303163 \mathrm{a} 0$

Brengman, L. A. (2015). Distinguishing Primary Versus Secondary Geochemical and Silicon Isotope Characteristics of Precambrian Chert and Iron Formation. Ph.D. Thesis, University of Tennessee.

Brennan, S. T., Lowenstein, T. K., and Horita, J. (2004). Seawater chemistry and the advent of biocalcification. Geology 32, 473-476. doi: 10.1130/G20251.1

Brocks, J. J., Jarrett, A. J. M., Sirantoine, E., Hallmann, C., Hoshino, Y., and Liyanage, T. (2017). The rise of algae in Cryogenian oceans and the emergence of animals. Nature 548, 578-581. doi: 10.1038/nature23457

Brown, J. W., and Sorhannus, U. (2010). A molecular genetic timescale for the diversification of autotrophic Stramenopiles (Ochrophyta): substantive underestimation of putative fossil ages. PLOS ONE 5:e12759. doi: 10.1371/journal.pone.0012759

Brzezinski, M. A., Sigman, D. M., Sarmiento, J. L., Matsumoto, K., Gruber, N., Rau, G. H., et al. (2002). A switch from $\mathrm{Si}(\mathrm{OH})_{4}$ to $\mathrm{NO}_{3}^{-}$depletion in the glacial Southern Ocean. Geophys. Res. Lett. 29:1564. doi: 10.1029/2001GL0 14349

Carey, J. C., and Fulweiler, R. W. (2012). The terrestrial silica pump. PLoS ONE 7:e52932. doi: 10.1371/journal.pone.0052932

Cermeño, P., Falkowski, P. G., Romero, O. E., Schaller, M. F., and Vallina, S. M. (2015). Continental erosion and the Cenozoic rise of marine diatoms. Proc. Natl. Acad. Sci. U.S.A. 112, 4239-4244. doi: 10.1073/pnas.1412883112

Chakrabarti, R. (2015). Silicon isotopes: from cosmos to benthos. Curr. Sci. 108, 246-254.

Chakrabarti, R., Knoll, A. H., Jacobsen, S. B., and Fischer, W. W. (2012). Si isotope variability in Proterozoic cherts. Geochim. Cosmochim. Acta 91, 187-201. doi: 10.1016/j.gca.2012.05.025

Chang, S., Feng, Q., Clausen, S., and Zhang, L. (2017). Sponge spicules from the lower Cambrian in the Yanjiahe Formation, South China: the earliest biomineralizing sponge record. Palaeogeogr. Palaeoclimatol. Palaeoecol. 474, 36-44. doi: 10.1016/j.palaeo.2016.06.032

Chi Fru, E., Hemmingsson, C., Mikaela Holm, M., Chiu, B., and Iñiguez, E. (2016). Arsenic-induced phosphate limitation under experimental Early Proterozoic oceanic conditions. Earth Planet. Sci. Lett. 434, 52-63. doi: 10.1016/j.epsl.2015.11.009

Chi Fru, E., Ivarsson, M., Kilias, S. P., Bengtson, S., Belivanova, V., Marone, F., et al. (2013). Fossilized iron bacteria reveal a pathway to the biological origin of banded iron formation. Nat. Commun. 4:2050. doi: 10.1038/ncomms3050

Chu, J. W. F., and Leys, S. P. (2010). High resolution mapping of community structure in three glass sponge reefs (Porifera, Hexactinellida). Mar. Ecol. Prog. Ser. 417, 97-113. doi: 10.3354/meps08794

Cohen, B. L. (2005). Not armour, but biomechanics, ecological opportunity and increased fecundity as keys to the origin and expansion of the mineralized benthic metazoan fauna. Biol. J. Linn. Soc. 85, 483-490. doi: $10.1111 / \mathrm{j} .1095-8312.2005 .00507 . \mathrm{x}$

Conley, D. J. (2002). Terrestrial ecosystems and the global biogeochemical silica cycle. Glob. Biogechem. Cycles 16:1121. doi: 10.1029/2002GB001894

Conley, D. J., and Carey, J. C. (2015). Silica cycling over geologic time. Nat. Geosci. 8, 431-432. doi: 10.1038/ngeo2454

Cui, H., Kaufman, A. J., Xiao, S., Peek, S., Cao, H., Min, X., et al. (2016). Environmental context for the terminal Ediacaran biomineralization of animals. Geobiology 14, 344-363. doi: 10.1111/gbi.12178

Cunningham, J. A., Liu, A. G., Bengtson, S., and Donoghue, P. C. J. (2017). The origin of animals: can molecular clocks and the fossil record be reconciled? Bioessays 39:1600120. doi: 10.1002/bies.201600120

De La Rocha, C. L. (2002). Measurement of silicon stable isotope natural abundances via multicollector inductively coupled plasma mass spectrometry (MC-ICP-MS). Geochem. Geophys. Geosyst. 3, 1-8. doi: 10.1029/2002GC000310

De La Rocha, C. L., and Bickle, M. J. (2005). Sensitivity of silicon isotopes to whole-ocean changes in the silica cycle. Mar. Geol. 217, 267-282. doi: 10.1016/j.margeo.2004.11.016
Delvigne, C. (2012). The Archaean Silicon Cycle Insights from Silicon Isotopes and Ge/Si Ratios in Banded Iron Formations, Palaeosols and Shales. Ph.D. Thesis. Universite Libre de Bruxelles, 181.

Delvigne, C., Cardinal, D., Hofmann, A., and André, L. (2012). Stratigraphic changes of $\mathrm{Ge} / \mathrm{Si}, \mathrm{REE}+\mathrm{Y}$ and silicon isotopes as insights into the deposition of a Mesoarchaean banded iron formation. Earth Planet. Sci. Lett. 355, 109-118. doi: 10.1016/j.epsl.2012.07.035

de Souza, G. F., Slater, R. D., Dunne, J. P., and Sarmiento, J. L. (2014). Deconvolving the controls on the deep ocean's silicon stable isotope distribution. Earth Planet. Sci. Lett. 398, 66-76. doi: 10.1016/j.epsl.2014.04.040

Ding, T. P., Gao, J. F., Tian, S. H., Fan, C. F., Zhao, Y., Wan, D. F., et al. (2017). The $\delta^{30} \mathrm{Si}$ peak value discovered in middle Proterozoic chert and its implication for environmental variations in the ancient ocean. Sci. Rep. 7:44000. doi: $10.1038 /$ srep44000

dos Reis, M., Thawornwattana, Y., Angelis, K., Telford, M. J., Donoghue, P. C. J., and Yang, Z. (2015). Uncertainty in the timing of origin of animals and the limits of precision in molecular timescales. Curr. Biol. 25, 2939-2950. doi: 10.1016/j.cub.2015.09.066

Dunn, C. W., Hejnol, A., Matus, D. Q., Pang, K., Browne, W. E., Smith, S. A., et al. (2008). Broad phylogenomic sampling improves resolution of the animal tree of life. Nature 452, 745-749. doi: 10.1038/nature06614

Durak, G. M., Taylor, A. R., Walker, C. E., Probert, I., Vargas, C., Audic, S., et al. (2016). A role for diatom-like silicon transporters in calcifying coccolithophores. Nat. Commun. 7:10543. doi: 10.1038/ncomms10543

Durkin, C., Koester, J. A., Bender, S. J., and Armbrust, E. V. (2016). The evolution of silicon transporters in diatoms. J. Phycol. 52, 716-731. doi: 10.1111/jpy.12441

Dvorák, P., Casamatta, D. A., Poulíčková, A., Hašler, P., Ondrej, V., and Sanges, R. (2014). Synechococcus: 3 billion years of global dominance. Mol. Ecol. 23, 5538-5551. doi: 10.1111/mec.12948

Edwards, D., Cherns, L., and Raven, J. A. (2015). Could land-based early photosynthesizing ecosystems have bioengineered the planet in mid-Palaeozoic times? Palaeontology 58, 803-837. doi: 10.1111/pala.12187

Egan, K., Rickaby, R. E. M., Hendry, K. R., and Halliday, A. N. (2013). Opening the gateways for diatoms primes Earth for Antarctic glaciation. Earth Planet. Sci. Lett. 375, 34-43. doi: 10.1016/j.epsl.2013.04.030

Eme, L., Sharpe, S. C., Brown, M. W., and Roger, A. J. (2014). On the age of eukaryotes: evaluating evidence from fossils and molecular clocks. Cold Spring Harb. Perspecti. Biol. 6:a016139. doi: 10.1101/cshperspect.a016139

Epstein, E. (1999). Silicon. Annu. Rev. Plant Physiol. Plant Mol. Biol. 50, 641-664. doi: 10.1146/annurev.arplant.50.1.641

Finkel, Z. V., Katz, M., Wright, J., Schofieid, O., and Falkowski, P. G. (2005). Climatically driven macroevolutionary patterns in the size of marine diatoms over the Cenozoic. Proc. Natl. Acad. Sci. U.S.A. 102, 8927-8932. doi: 10.1073/pnas.0409907102

Finkel, Z. V., and Kotrc, B. (2010). Silica use through time: macroevolutionary change in the morphology of the diatom fustule. Geomicrobiol. J. 27, 596-608. doi: 10.1080/01490451003702941

Finkel, Z. V., Matheson, K. A., Regan, K. S., and Irwin, A. J. (2010). Genotypic and phenotypic variation in diatom silicification under paleo-oceanographic conditions. Geobiology 8, 433-445. doi: 10.1111/j.1472-4669.2010. 00250.x

Fischer, W. W., and Knoll, A. H. (2009). An iron shuttle for deepwater silica in Late Archean and early Paleoproterozoic iron formation. GSA Bull. 121, 222-235. doi: 10.1130/B26328.1

Flombaum, P., Gallegos, J. L., Gordillo, R. A., Rincóna, J., Zabala, L. L., Jiao, N., et al. (2013). Present and future global distributions of the marine Cyanobacteria Prochlorococcus and Synechococcus. Proc. Natl. Acad. Sci. U.S.A. 110, 9824-9829. doi: 10.1073/pnas.1307701110

Fontorbe, G., Frings, P. J., De La Rocha, C. L., Hendry, K. R., and Conley, D. J. (2016). A silicon depleted North Atlantic since the Palaeogene: evidence from sponge and radiolarian silicon isotopes. Earth Planet. Sci. Lett. 453, 67-77. doi: 10.1016/j.epsl.2016.08.006

Fontorbe, G., Frings, P. J., De La Rocha, C. L., Hendry, K. R., and Conley, D. J. (2017). Enrichment of dissolved silica in the deep Equatorial Pacific during the Eocene-Oligocene. Paleoceanography 32, 848-863. doi: 10.1002/2017PA0 03090 
Frings, P. J., Clymans, W., and Conley, D. J. (2014). Amorphous silica transport in the Ganges basin: implications for Si delivery to the oceans. Proc. Earth Planet. Sci. 10, 271-274. doi: 10.1016/j.proeps.2014.08.059

Frings, P. J., Clymans, W., Fontorbe, G., De La Rocha, C. L., and Conley, D. J. (2016). The continental Si cycle and its impact on the ocean Si isotope budget. Chem. Geol. 425, 12-36. doi: 10.1016/j.chemgeo.2016.01.020

Frings, P. J., Clymans, W., Fontorbe, G., Gray, W., Govind, C., Conley, D. J., et al. (2015). Silicate weathering in the Ganges alluvial plain. Earth Planet. Sci. Lett. 427, 136-148. doi: 10.1016/j.epsl.2015.06.049

Geilert, S., Vroon, P. Z., and van Bergen, M. J. (2014). Silicon isotopes and trace elements in chert record early Archean basin evolution. Chem. Geol. 386, 133-142. doi: 10.1016/j.chemgeo.2014.07.027

Georg, R. B., West, A. J., Basu, A. R., and Halliday, A. N. (2009). Silicon fluxes and isotope composition of direct groundwater discharge into the Bay of Bengal and the effect on the global ocean silicon budget. Earth Planet. Sci. Lett. 283, 67-74. doi: 10.1016/j.epsl.2009.03.041

Gouretski, V., and Koltermann, K. P. (2004). WOCE global hydrographic climatology. Berichte BSH 35, 1-52.

Graham, L. E., and Wilcox, L. W. (2000). Algae. Upper Saddle River, NJ: PrenticeHall.

Gunnarsson, I., and Arnórsson, S. (2000). Amorphous silica solubility and the thermodynamic properties of $\mathrm{H}_{4} \mathrm{SiO}_{4}^{\circ}$ in the range of

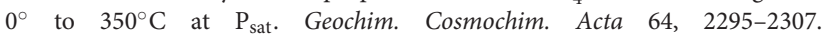
doi: $10.1016 /$ S0016-7037(99)00426-3

Harper, H. E., and Knoll, A. H. (1975). Silica, diatoms, and Cenozoic radiolarian evolution. Geology 3, 175-177.

Hawkings, J. R., Wadham, J. L., Benning, L. G., Hendry, K. R., Tranter, M., Tedstone, A., et al. (2017). Ice sheets as a missing source of silica to the polar oceans. Nat. Commun. 8:14198. doi: 10.1038/ncomms14198

Heck, P. R., Huberty, J. M., Kita, N. T., Ushikubo, T., Kozdon, R., and Valley, J. W. (2011). SIMS analyses of silicon and oxygen isotope ratios for quartz from Archean and Paleoproterozoic banded iron formations. Geochim. Cosmochim. Acta 75, 5879-5891. doi: 10.1016/j.gca.2011.07.023

Hendry, K. R., and Brzezinski, M. A. (2014). Using silicon isotopes to understand the role of the Southern Ocean in modern and ancient biogeochemistry and climate Q. Sci. Rev. 89, 13-26. doi: 10.1016/j.quascirev.2014.01.019

Hendry, K. R., Gong, X., Knorr, G., Pike, J., and Hall, I. R. (2016). Deglacial diatom production in the tropical North Atlantic driven by enhanced silicic acid supply. Earth Planet. Sci. Lett. 438, 122-129. doi: 10.1016/j.epsl.2016. 01.016

Hendry, K. R., and Robinson, L. F. (2012). The relationship between silicon isotope fractionation in sponges and silicic acid concentration: Modern and core-top studies of biogenic opal. Geochim. Cosmochim. Acta 81, 1-12. doi: 10.1016/j.gca.2011.12.010

Hildebrand, M. (2000). "Silicic acid transport and its control during cell wall silicification in diatoms," in Biomineralization, ed E. Bäuerlein (Weinheim: Springer), 171-188.

Hodson, M. J., White, P. J., Mean, A., and Broadley, M. R. (2005). Phylogenetic variation in the silicon composition of plants. Ann. Bot. 96, 1027-1046. doi: $10.1093 / \mathrm{aob} / \mathrm{mci} 255$

Hori, K., and 49 co-authors. (2014). Klebsormidium flaccidum genome reveals primary factors for plant terrestrial adaptation. Nat. Commun. 5:3978. doi: $10.1038 /$ ncomms 4978

Hu, G. Y., Fan, C. F., Wan, D. F., Li, Y. H., and Chen, S. M. (2013). Geochemistry of bedded cherts in the cap carbonates in Three Gorges Region, Hubei Province, and its paleoenvironmental implications. Acta Geol. Sin. 87, 1469-1476. doi: 10.1016/j.palaeo.2016.10.004

Jessen, G. L., Lichtschlag, A., Ramette, A., Pantoja, S., Rossel, P. E., Schubert, C., et al. (2017). Hypoxia causes preservation of labile organic matter and changes seafloor microbial community composition (Black Sea). Sci. Adv. 3:e1601897. doi: $10.1126 /$ sciadv.1601897

Jones, C., Nomosatryo, S., Crowe, S. A., Berrum, C. J., and Canfield, D. E. (2015). Iron oxides, divalent cations, silica, and the early earth phosphorus crisis. Geology 43, 135-138. doi: 10.1130/G36044.1

Kahn, A. S., Ruhl, H. A., and Smith, K. L. (2012). Temporal changes in deep-sea sponge populations are correlated to changes in surface climate and food supply. Deep Sea Res. I 70, 36-41. doi: 10.1016/j.dsr.2012. 08.001
Katz, M. E., Finkel, Z. V., Grzebyk, D., Knoll, A. H., and Falkowski, P. G. (2004). Evolutionary trajectories and biogeochemical impacts of marine eukaryotic phytoplankton. Annu. Rev. Ecol. Evol. Syst. 35, 523-556. doi: 10.1146/annurev.ecolsys.35.112202.130137

Kidder, D. L., and Erwin, D. H. (2001). Secular distribution of biogenic silica through the Phanerozoic: comparison of silica-replaced fossils and bedded cherts at the series level. J. Geol. 109, 509-522. doi: 10.1086/ 320794

Kidder, D. L., and Tomescu, I. (2016). Biogenic chert and the Ordovician silica cycle. Palaeogeogr. Palaeoclimatol. Palaeoecol. 458, 29-38. doi: 10.1016/j.palaeo.2015.10.013

Kidder, D. L., and Worsley, T. R. (2010). Phanerozoic Large Igneous Provinces (LIPs), HEATT (Haline Euxinic Acidic Thermal Transgression) episodes, and mass extinctions. Palaeogeogr. Palaeoclimatol. Palaeoecol. 295, 162-191. doi: 10.1016/j.palaeo.2010.05.036

Klein, C. (2005). Some Precambrian banded iron-formations (BIFs) from around the world: their age, geologic setting, mineralogy, metamorphism, geochemistry, and origin. Amer. Mineral. 90, 1473-1499. doi: $10.2138 / \mathrm{am} .2005 .1871$

Knoll, A. H. (2003). Biomineralization and evolutionary history. Rev. Mineral. Geochem. 54, 329-356. doi: 10.2113/0540329

Knoll, A. H. (2017). Food for animal evolution. Nature 548, 528-530. doi: 10.1038 /nature23539

Knoll, A. H., and Follows, M. J. (2016). A bottom-up perspective on ecosystem change in Mesozoic oceans. Proc. R. Soc. B 283:20161755. doi: $10.1098 / \mathrm{rspb} .2016 .1755$

Knoll, A. H., and Kotrc, B. (2015). "Protistan skeletons: a geologic history of evolution and constraint," in Evolution of Lightweight Structures, ed C. Hamm (Dordrecht: Springer), 1-16.

Konhauser, K. O., Amskolda, L., Lalondea, S. V., Posthb, N. R., Kapplerb, A., and Anbarc, A. (2007). Decoupling photochemical Fe(II) oxidation from shallow-water BIF deposition. Earth Planet. Sci. Lett. 258, 87-100. doi: 10.1016/j.epsl.2007.03.026

Konhauser, K. O., Jones, B., Phoenix, V. R., Ferris, G., and Renaut, R. W. (2004). The microbial role in hot spring silicification. Ambio 33, 552-558. doi: 10.1579/0044-7447-33.8.552

Kotrc, B., and Knoll, A. H. (2015). A morphospace of planktonic marine diatoms. I. Two views of disparity through time. Paleobiology 41, 45-67. doi: $10.1017 /$ pab.2014.4

Kump, L. R. (2008). The rise of atmospheric oxygen. Nature 451, 277-278. doi: 10.1038/nature06587

Laruelle, G. G., Roubeix, V., Sferratore, A., Brodhern, B., Ciuffa, D., Conley, D. J., et al. (2009). Anthropogenic perturbations of the silicon cycle at the global scale: Key role of the land-ocean transition. Glob. Biogeochem. Cycles 23:GB4031. doi: 10.1029/2008GB003267

Lazarus, D., Barron, J., Renaudie, J., Diver, P., and Türke, A. (2014). Cenozoic planktonic marine diatom diversity and correlation to climate change. PLoS ONE 9:e84857. doi: 10.1371/journal.pone.0084857

Lazarus, D. B., Kotrc, B., Wulf, G., and Schmidt, D. N. (2009). Radiolarians decreased silicification as an evolutionary response to reduced Cenozoic ocean silica availability. Proc. Natl. Acad. Sci. U.S.A. 106, 9333-9338. doi: 10.1073/pnas.0812979106

Leadbeater, B. S. C., and Jones, W. C. (1984). Silicification of 'cell walls' of certain protistan flagellates [and Discussion]. Proc. R. Soc. B 304, 529-536. doi: 10.1098/rstb.1984.0044

Lenton, T. M., Crouch, M., Johnson, M., Pires, N., and Dolan, L. (2012). First plants cooled the Ordovician. Nat. Geosci. 5, 86-89. doi: 10.1038/ngeo1390

Lenton, T. M., and Daines, S. J. (2017). Biogeochemical transformations in the history of the ocean. Ann. Rev. Mar. Sci. 9, 31-58. doi: 10.1146/annurev-marine-010816-060521

Li, Y., Hou, K., Wan, D., Zhang, Z., and Yue, G. (2014). Precambrian banded iron formations in the North China Craton: silicon and oxygen isotopes and genetic implications. Ore Geol. Rev. 57, 299-307. doi: 10.1016/j.oregeorev.2013.09.011

Ma, J. F., and Yamaji, N. (2015). A cooperative system of silicon transport in plants. Trends Plant Sci. 20, 435-442. doi: 10.1016/j.tplants.2015.04.007

Ma, J. F., Yamaji, N., Mitani, N., Tamai, K., Konishi, S., Fujiwara, T., et al. (2007). An efflux transporter of silicon in rice. Nature 448, 209-212. doi: $10.1038 /$ nature05964 
Ma, J. F., Yamaji, N., Mitani, N., Xu, X.-Y., Su, Y.-H., McGrath, S. P., et al. (2008). Transporters of arsenite in rice and their role in arsenic accumulation in rice grain. Proc. Natl. Acad. Sci. U.S.A. 105, 9931-9935. doi: $10.1073 /$ pnas.0802361105

Mackenzie, F. T., Garrels, R. M., Bricker, O. P., and Bickley, F. (1967). Silica in water: control by silica minerals. Science 155, 1404-1405. doi: $10.1126 /$ science.155.3768.1404

Maldonado, M., Aguilar, R., Blanco, J., García, S., Serrano, A., and Punzón, A. (2015). Aggregated clumps of lithistid sponges: a singular, reef-like bathyal habitat with relevant paleontological connections. PLOS ONE 10:e125378. doi: 10.1371/journal.pone.0125378

Maldonado, M., Carmona, M. C., and Cruzado, A. (1999). Decline in Mesozoic reef-building in sponges explained by silicon limitation. Nature 401, 785-788. doi: $10.1038 / 44560$

Maliva, R. G., Knoll, A. H., and Siever, R. (1989). Secular change in chert distribution: a reflection of evolving biological participation in the silica cycle. Palaios 4, 519-532. doi: 10.2307/3514743

Maliva, R. G., Knoll, A. H., and Simonson, B. M. (2005). Secular change in the Precambrian silica cycle: insights from chert petrology. GSA Bull. 117, 835-845. doi: 10.1130/B25555.1

Marchetti, A., and Cassar, N. (2009). Diatom elemental and morphological changes in responseto iron limitation: a brief review with potentialpaleoceanographic applications. Geobiology 7, 419-431. doi: 10.1111/j.1472-4669.2009. 00207.x

Marin-Carbonne, J., Robert, F., and Chaussidon, M. (2014). The silicon and oxygen isotope compositions of Precambrian cherts: a record of oceanic paleo-temperatures? Precambrian Res. 247, 223-234. doi: 10.1016/j.precamres.2014.03.016

Markovich, O., Steinera, E., Kourilb, Š., Tarkowski, P., Aharoni, A., and Elbaum, R. (2017). Silicon promotes cytokinin biosynthesis and delays senescence in Arabidopsis and Sorghum. Plant Cell Environ. 40, 1189-1196. doi: $10.1111 /$ pce. 12913

Marron, A. O., Alston, M. J., Heavens, D., Akam, M., Caccamo, M., Holland, P. W. H., et al. (2013). A family of diatom-like silicon transporters in the siliceous loricate choanoflagellates. Proc. R. Soc. B 280:20122543. doi: $10.1098 / \mathrm{rspb} .2012 .2543$

Marron, A. O., Ratcliffe, S., Wheeler, G. L., Goldstein, R. E., Nicole King, N., Not, F., et al. (2016). The evolution of silicon transport in eukaryotes. Mol. Biol. Evol. 33, 3226-3248. doi: 10.1093/molbev/msw209

McKenzie, N. R., Horton, B. K., Loomis, S. E., Stockli, D. F., Planavsky, N. J., and Cin-Ty, A. L. (2016). Continental arc volcanism as the principal driver of icehouse-greenhouse variability. Science 352, 444-447. doi: 10.1126/science.aad5787

Meckler, A. N., Sigman, D. M., Gibson, K. A., Francois, R., MartinexGarcia, A., Jaccard, S. L., et al. (2013). Deglacial pulses of deep-ocean silicate into the subtropical North Atlantic Ocean. Nature 495, 495-498. doi: $10.1038 /$ nature12006

Medlin, L. K., Kooistra, W. H., Gersonde, R., and Wellbrock, U. (1996). Evolution of the diatoms (Bacillariophyta). II. Nuclear-encoded small-subunit rRNA sequence comparisons confirm a paraphyletic origin for the centric diatoms. Mol. Biol. Evol. 13, 67-75. doi: 10.1093/oxfordjournals.molbev. a025571

Milligan, A. J., and Morel, F. M. M. (2002). A proton buffering role for silica in diatoms. Science 297, 1848-1850. doi: 10.1126/science.1074958

Misra, S., and Froelich, P. N. (2012). Lithium isotope history of Cenozoic seawater: changes in silicate weathering and reverse weathering. Science 335, 818-823. doi: 10.1126/science. 1214697

Moore, T. C. (2008). Biogenic silica and chert in the Pacific Ocean. Geology 36, 975-978. doi: 10.1130/G25057A.1

Moulton, K. L., and Berner, R. A. (1988). Quantification of the effect of plants on weathering: studies in Iceland. Geology 26, 895-898.

Muttoni, G., and Kent, D. V. (2007). Widespread formation of cherts during the early Eocene climate optimum. Palaeogeogr. Palaeoclimatol. Palaeoecol. 253, 348-362. doi: 10.1016/j.palaeo.2007.06.008

Ohnemus, D. C., Rauschenberg, S., Krause, J. W., Brzezinski, M. A., Collier, J. L., Gerachi-Yee, J., et al. (2016). Silicon content of individual cells of Synechococcus from the North Atlantic Ocean. Mar. Chem. 187, 16-24. doi: 10.1016/j.marchem.2016.10.003
Pagani, M., Caldeira, K., Berner, R., and Beerling, D. J. (2009). The role of terrestrial plants in limiting atmospheric $\mathrm{CO}_{2}$ decline over the past 24 million years. Nature 460, 85-89. doi: 10.1038/nature 08133

Parfrey, L. W., Lahr, D. J. G., Knoll, A. H., and Katz, L. (2011). Estimating the timing of early eukaryotic diversification with multigene molecular clocks. Proc. Natl. Acad. Sci. U.S.A. 108, 13624-13629. doi: 10.1073/pnas.1110633108

Pogge von Strandmann, P. A. E., Desrochers, A., Murphy, M. J., Finlay, A. J., Selby, D., and Lenton, T. M. (2017). Global climate stabilisation by chemical weathering during the Hirnantian glaciation. Geochem. Perspect. Lett. 3, 230-237. doi: 10.7185/geochemlet.1726

Pogge von Strandmann, P. A. E., and Hendersen, G. (2015). The Li isotope response to mountain uplift. Geology 43, 67-70. doi: 10.1130/G36162.1

Pollard, R. T., Lucas, M. I., and Read, J. F. (2002). Physical controls on biogeochemical zonation in the Southern Ocean. Deep Sea Res. II 49, 3289-3305. doi: 10.1016/S0967-0645(02)00084-X

Pondaven, P., Gallinari, M., Chollet, S., Bucciarelli, E., Sarthou, G., Schultes, S., et al. (2007). Grazing-induced changes in cell wall silicification in a marine diatom. Protist 158, 21-28. doi: 10.1016/j.protis.2006.09.002

Porter, S. M., and Knoll, A. H. (2000). Testate amoebae in the Neoproterozoic Era: evidence from vase-shaped microfossils in the Chuar Group, Grand Canyon. Paleobiology 26, 360-385.

Quirk, J., Leake, J. R., Johnson, D. A., Taylor, L. L., Saccone, L., and Beerling, D. J. (2015). Constraining the role of early land plants in Palaeozoic weathering and global cooling. Proc. R. Soc. B 282:20151115. doi: 10.1098/rspb.2015.1115

Rabosky, D. L., and Sorhannus, U. (2009). Diversity dynamics of marine planktonic diatoms across the Cenozoic. Nature 457, 183-173. doi: $10.1038 /$ nature 07435

Racki, G., and Cordey, F. (2000). Radiolarian palaeoecology and radiolarites: is the present the key to the past? Earth Sci. Rev. 52, 83-120. doi: 10.1016/S0012-8252(00)00024-6

Rahman, S., Aller, R. C., and Cochran, J. K. (2016). Cosmogenic ${ }^{32} \mathrm{Si}$ as a tracer of biogenic silica burial and diagenesis: Major deltaic sinks in the silica cycle. Geophys. Res. Lett. 43, 7124-7132. doi: 10.1002/2016GL069929

Ramseyer, K., Amthor, J. E., Matter, A., Pettke, T., Wille, M., and Fallick, A. E. (2013). Primary silica precipitate at the Precambrian/Cambrian boundary in the south Oman salt basin, sultanate of Oman. Mar. Petrol. Geol. 39, 187-197. doi: 10.1016/j.marpetgeo.2012.08.006

Rasmussen, B., Krapež, B., Muhling, J. R., and Suvorova, A. (2015). Precipitation of iron silicate nanoparticles in early Precambrian oceans marks Earth's first iron age. Geology 43, 303-306. doi: 10.1130/G36309.1

Raven, J. A., and Waite, A. M. (2004). The evolution of silicification in diatoms: inescapable sinking and sinking as escape? New Phytol. 162, 45-61. doi: 10.1111/j.1469-8137.2004.01022.x

Reddy, T. R., Zheng, X. -Y., Roden, E. E., Beard, B. L., and Johnson, C. M. (2016). Silicon isotope fractionation during microbial reduction of Fe(III)-Si gels under Archean seawater conditions and implications for iron formation genesis. Geochim. Cosmochim. Acta 190, 85-99. doi: 10.1016/j.gca.2016.06.035

Renaudie, J. (2016). Quantifying the Cenozoic marine diatom deposition history: links to the $\mathrm{C}$ and $\mathrm{Si}$ cycles. Biogeosciences 13, 6003-6014. doi: 10.5194/bg-13-6003-2016

Rickaby, R. E. M. (2015). Goldilocks and the three inorganic equilibria: how Earth's chemistry and life coevolve to be nearly in tune. Philos. Trans. R. Soc. A 373:20140188. doi: 10.1098/rsta.2014.0188

Ritterbush, K. A., Rosas, S., Corsetti, F. A., Bottjer, D. J., and West, A. J. (2015). Andean sponges reveal long-term benthic ecosystem shifts following the endTriassic mass extinction. Palaeogeogr. Palaeoclimatol. Palaeoecol. 420, 193-209. doi: $10.1016 /$ j.palaeo.2014.12.002

Robert, F., and Chaussidon, M. (2006). A palaeotemperature curve for the Precambrian oceans based on silicon isotopes in cherts. Nature 443, 969-972. doi: 10.1038 /nature05239

Sanchez-Baracaldoa, P., Raven, J. A., Pisani, D., and Knoll, A. H. (2017). Early photosynthetic eukaryotes inhabited low-salinity habitats. Proc. Natl. Acad. Sci. U.S.A. 114, E7737-E7745. doi: 10.1073/pnas.1620089114

Sanchez-Baracaldo, P. (2015). Origin of marine planktonic cyanobacteria. Sci. Rep. 5:17418. doi: $10.1038 /$ srep 17418

Sarmiento, J. L., Gruber, N., Brzezinski, M. A., and Dunne, J. P. (2004). High-latitude controls of thermocline nutrients and low latitude biological productivity. Nature 427, 56-60. doi: 10.1038/nature02127 
Schneider, S. H., and Boston, P.J. (eds.). (1991). Scientists on Gaia. Massachusetts Institute of Technology, The MIT Press.

Schirrmeister, B. E., Sanchez-Baracaldo, P., and Wacey, D. (2016). Cyanobacterial evolution during the Precambrian. Int. J. Astrobiology 15, 187-204. doi: $10.1017 /$ S1473550415000579

Schubert, J., Kidder, D. L., and Erwin, D. H. (1997). Silica-replaced fossils through the Phanerozoic. Geology 25, 1031-1034.

Schwartzman, D. W., and Volk, T. (1989). Biotic enhancement of weathering and the habitability of Earth. Nature 340, 457-460. doi: 10.1038/340457a0

Siever, R. (1991). "Silica in the oceans: biological-geochemical interplay," in Scientists on Gaia, eds S. H. Schneider and P. J. Boston (Cambridge, MA: MIT Press), 287-295.

Siever, R. (1992). The silica cycle in the Precambrian. Geochim. Cosmochim. Acta 56, 3265-3272. doi: 10.1016/0016-7037(92)90303-Z

Sims, P. A., Mann, D. G., and Medlin, L. K. (2006). Evolution of the diatoms: insights from fossil, biological and molecular data. Phycologia 45, 361-402. doi: $10.2216 / 05-22.1$

Smith, J. M., and Szathmáry, E. (1995). The Major Transitions in Evolution. Oxford: Oxford University Press.

Sperling, E. A., Robinson, J. M., Pisani, D., and Peterson, K. J. (2010). Where's the glass? Biomarkers, molecular clocks, and microRNAs suggest a $200-\mathrm{Myr}$ missing Precambrian fossil record of siliceous sponge spicules. Geobiology 8, 24-36. doi: 10.1111/j.1472-4669.2009.00225.x

Stefurak, E. J., Fischer, W. W., and Lowe, D. R. (2015). Texture-specific Si isotope variations in Barberton Greenstone Belt cherts record low temperature fractionations in early Archean seawater. Geochim. Cosmochim. Acta 150, 26-52. doi: 10.1016/j.gca.2014.11.014

Stefurak, E. J. T., Lowe, D. R., Zentner, D., and Fischer, W. W. (2014). Primary silica granules - A new mode of Paleoarchean sedimentation. Geology 42, 283-286. doi: 10.1130/G35187.1

Steinhoefel, G., Horn, I., and von Blanckenburg, F. (2009). Micro-scale tracing of $\mathrm{Fe}$ and $\mathrm{Si}$ isotope signatures in banded iron formation using femtosecond laser ablation. Geochim. Cosmochim. Acta 73, 5343-5360. doi: 10.1016/j.gca.2009.05.037

Steinhoefel, G., von Blanckenburg, F., Horn, I., Konhauser, K. O., Beukes, N. J., and Gutzmer, J. (2010). Deciphering formation processes of banded iron formations from the Transvaal and the Hamersley successions by combined $\mathrm{Si}$ and $\mathrm{Fe}$ isotope analysis using UV femtosecond laser ablation. Geochim. Cosmochim. Acta 74, 2677-2696. doi: 10.1016/j.gca.2010.01.028

Street-Perrott, F. A., and Barker, P. A. (2008). Biogenic silica: a neglected component of the coupled global continental biogeochemical cycles of carbon and silicon. Earth Surf. Proc. Landf. 33, 1436-1457. doi: 10.1002/esp.1712

Struyf, E., and Conley, D. J. (2012). Emerging understanding of the ecosystem silica buffer. Biogeochemistry 107, 9-18. doi: 10.1007/s10533-011-9590-2

Struyf, E., Smis, A., Van Damme, S., Garnier, J., Govers, G., Van Wesemae, B., et al. (2010). Historical land use change has lowered terrestrial silica mobilization. Nat. Commun. 1:129. doi: 10.1038/ncomms1128

Sunagawa, S., Coelho, L. P., Chaffron, S., Kultima, J. R., Labadie, K., Salazar, G., et al. (2015). Structure and function of the global ocean microbiome. Science 348:1261359. doi: 10.1126/science.1261359

Tang, T., Kisslinger, K., and Lee, C. (2014). Silicate deposition during decomposition of cyanobacteria may promote export of picophytoplankton to the deep ocean. Nat. Commun. 5:4143. doi: 10.1038/ncomms5143

Thamatrakoln, K., and Hildebrand, M. (2008). Silicon uptake in diatoms revisited: a model for saturable and nonsaturable uptake kinetics and the role of silicon transporters. Plant Physiol. 146, 1397-1407. doi: 10.1104/pp.107.107094

Tréguer, P. J., and De La Rocha, C. L. (2013). The world ocean silica cycle. Ann. Rev. Mar. Sci. 5, 477-501. doi: 10.1146/annurev-marine-121211-172346

Trembath-Reichert, E., Wilson, J. P., McGlynn, S. E., and Fischer, W. W. (2015). Four hundred million years of silica biomineralization in land plants. Proc. Natl. Acad. Sci. U.S.A. 112, 5449-5454. doi: 10.1073/pnas.1500289112

Uriz, M. -J. (2006). Mineral skeletogenesis in sponges. Can. J. Zool. 84, 322-356. doi: $10.1139 /$ z06-032

Van Cappellen, P. (2003). Biomineralization and global biogeochemical cycles. Rev. Mineral. Geochem. 54, 357-381. doi: 10.2113/0540357
Van Cappellen, P., Dixit, S., and van Beusekom, J. (2002). Biogenic silica dissolution in the oceans: Reconciling experimental and field-based dissolution rates. Glob. Biogechem. Cycles 16:1075. doi: 10.1029/2001GB 001431

van den Boorn, S. H., van Bergen, M. J., Nijman, W., and Vroon, P. Z. (2007). Dual role of seawater and hydrothermal fluids in Early Archean chert formation: evidence from silicon isotopes. Geology 35, 939-942. doi: 10.1130/ G24096A.1

van den Boorn, S. H. J. M., van Bergen, M. J., Vroon, P. Z., de Vries, S. T., and Nijman, W. (2010). Silicon isotope and trace element constraints on the origin of $\sim 3.5 \mathrm{Ga}$ cherts: implications for Early Archaean marine environments. Geochim. Cosmochim. Acta 74, 1077-1103. doi: 10.1016/j.gca.2009.09.009

Van de Poel, B., Cooper, E. D., Van Der Straeten, D., Chang, C., and Delwiche, C. F. (2016). Transcriptome profiling of the green alga Spirogyra pratensis (Charophyta) suggests an ancestral role for ethylene in cell wall metabolism, photosynthesis, and abiotic stress responses. Plant Physiol. 172, 533-545. doi: 10.1104/pp.16.00299

Vanneste, K., Sterck, L., Myburg, A. A., Van de Peer, Y., and Mizrachic, E. (2015). horsetails are ancient polyploids: evidence from Equisetum giganteum. Plant Cell 27, 1567-1578. doi: 10.1105/tpc.15.00157

van Tol, H. M., Irwin, A. J., and Finkel, Z. V. (2012). Macroevolutionary trends in silicoflagellate skeletal morphology: the costs and benefits of silicification. Paleobiology 38, 391-402. doi: 10.1666/11022.1

Walker, J. C. G., Hays, P. B., and Kasting, J. F. (1981). A negative feedback mechanism for the long-term stabilization of Earth's surface-temperature. J. Geophys. Res. Oceans Atmosp. 86, 9776-9782. doi: 10.1029/JC086iC10 p09776

Wen, H., Fan, H., Tian, S., Wang, Q., and Hu, R. (2016). The formation conditions of the early Ediacaran cherts, South China. Chem. Geol. 430, 45-69. doi: 10.1016/j.chemgeo.2016.03.005

West, A. J., Galy, A., and Bickle, M. (2005). Tectonic and climatic controls on silicate weathering. Earth Planet. Sci. Lett. 235, 211-228. doi: 10.1016/j.epsl.2005.03.020

Wille, M., Sutton, J., Ellwood, M. J., Sambridge, M., Maher, W., Eggins, S., et al. (2010). Silicon isotopic fractionation in marine sponges: a new model for understanding silicon isotopic fractionation in sponges. Earth Planet. Sci. Lett. 292, 281-289. doi: 10.1016/j.epsl.2010.01.036

Yamada, K., Yoshikawa, S., Ichinomiya, M., Kuwata, A., Kamiya, M., and Ohki, K. (2014). Effects of silicon-limitation on growth and morphology of Triparma laevis NIES-2565 (Parmales, Heterokontophyta). PLoS ONE 9:e103289. doi: 10.1371/journal.pone.0103289

Yee, N., Phoenix, V. R., Konhauser, K. O., Benning, L. G., and Ferris, F. G. (2003). The effect of cyanobacteria on silica precipitation at neutral $\mathrm{pH}$ : Implications for bacterial silicification in geothermal hot springs. Chem. Geol. 199, 83-90. doi: 10.1016/S0009-2541(03)00120-7

Yool, A., and Tyrrell, T. (2005). Implications for the history of Cenozoic opal deposition from a quantitative model. Palaeogeogr. Palaeoclimatol. Palaeoecol. 218, 239-255. doi: 10.1016/j.palaeo.2004.12.017

Zheng, X. -Y., Beard, B. L., Reddy, T. R., Roden, E. E., and Johnson, C. M. (2016). Abiologic silicon isotope fractionation between aqueous $\mathrm{Si}$ and $\mathrm{Fe}(\mathrm{III})-$ Si gel in simulated Archean seawater: implications for Si isotope records in Precambrian sedimentary rocks. Geochim. Cosmochim. Acta 187, 102-122. doi: 10.1016/j.gca.2016.05.012

Conflict of Interest Statement: The authors declare that the research was conducted in the absence of any commercial or financial relationships that could be construed as a potential conflict of interest.

Copyright (c) 2017 Conley, Frings, Fontorbe, Clymans, Stadmark, Hendry, Marron and De La Rocha. This is an open-access article distributed under the terms of the Creative Commons Attribution License (CC BY). The use, distribution or reproduction in other forums is permitted, provided the original author(s) or licensor are credited and that the original publication in this journal is cited, in accordance with accepted academic practice. No use, distribution or reproduction is permitted which does not comply with these terms. 